\title{
What Fueled the Far-Reaching Impact of the Windhoek Declaration and Namibia Plan of Action as a Milestone for Gender Mainstreaming in UN Peace Support Operations and Where Is Implementation 20 Years Later?
}

\author{
Nina J. Lahoud* \\ New York City, New York, United States \\ nina.lahoud@gmail.com
}

\begin{abstract}
Acknowledging that progress in gender mainstreaming was woefully deficient, the United Nations (UN) Department of Peacekeeping Operations organized a May 2000 Seminar in Windhoek on "Mainstreaming a Gender Perspective in Multidimensional Peace Support Operations", hosted by the Namibian Government, which produced two ground-breaking outcome documents that had an enormous impact on the adoption of landmark UN Security Council resolution 1325 on "Women and peace and security" five
\end{abstract}

* Nina Lahoud is currently a member of the Board of Directors of the International Legal Assistance Consortium (ILAC), the Global Leadership Council of Seeds of Peace, and the Advisory Board of PassBlue. Appointed by the Office of the UN Secretary-General, she also serves as a member of the Advisory Group to the UN High-Level Task Force on Financing for Gender Equality. She was selected as a 2013-2014 Harvard University Advanced Leadership Initiative Senior Fellow, and developed a project for establishing a "Network of Gender Justice Mentors and Peers" with the pilot phase implemented in Timor-Leste with women lawyers and judges and their counterparts in other countries (see http://harvardmagazine.com/2014/og/globalcharge). Her decision to leave a Wall Street law firm in 1983 to join the UN peacekeeping force in Lebanon (UNIFIL) as the first woman Legal Adviser ever appointed to a mission began her 33-year UN career dealing with rule of law, peacekeeping, peacebuilding, development and gender issues while serving at Headquarters offices and in six UN peacekeeping operations (in Lebanon, Namibia, Cambodia, Croatia, Kosovo, East Timor) at critical historical junctures. She handled diverse peacekeeping matters in the UN Office of Legal Affairs for a decade before moving to the Department of Peacekeeping Operations (DPKO) in 1997 during a surge in peacekeeping worldwide. During two decades there, she assumed wide-ranging functions, including as Principal Officer to the Assistant Secretary-General for Peacekeeping in $2015^{-2016}$, where she also developed proposals for strengthening the gender architecture 
months later. Through the lens of the author's first-hand account, the article unpacks and scrutinizes the ways in which the Seminar's visionary Windhoek Declaration and the more operational Namibia Plan of Action came into being and had such a critical impact on that milestone resolution, and what specific factors ignited this exceptional outcome, including the role played by the host country. Through this prism, three key factors and the infectious effect of each are described, providing insights into the evolving Seminar dynamics and the interplay of inspiring speakers, Working Group deliberations, and strategic plenary sessions. The article also highlights, however, that the promises of the Windhoek Declaration, Namibia Plan of Action, and resolution 1325 have still not been fulfilled twenty years later, even though the hopes of conflict-affected women had been re-ignited in 2015 with Security Council resolution 2242's sweeping calls for action and a stark Global Study on the Implementation of United Nations Security Council Resolution 1325 presenting robust recommendations for action to fill the many gaps. As the $20^{\text {th }}$ anniversary of resolution 1325 approaches, a rallying cry of hope is directed to all those who believe in the need for women to be fully involved as equal partners in all peace and security processes that this struggle can still be accelerated to achieve the results envisaged if top UN leadership spearheads a bold time-bound initiative to steer the course forward. But will this rallying cry be embraced?

\section{Keywords}

United Nations - peacekeeping operations - peace support missions - women and peace and security - women in peacekeeping - gender mainstreaming - Windhoek Declaration - Namibia Plan of Action - Security Council resolution 1325 - Namibia Kosovo - East Timor

of peacekeeping missions and gender expertise throughout mission planning processes (which were shared with three high-level review panels appointed by the Secretary-General). Earlier, she served as D Pко's Deputy Director-Middle East Division, Special Assistant to the Under-Secretary-General for Peacekeeping Operations, and Head of the Rule of Law Project (spearheading the Secretary-General's Executive Committee 'Task Force for the Development of Comprehensive Rule of Law Strategies for Peace Operations' and appointed as a member and secretariat head). She also served with other UN entities, including as Principal Officer to the Secretary-General's Special Adviser on Iraq, Gender Adviser to the Executive Secretary/ UN Economic and Social Commission for Asia and the Pacific (UN-EscaP), and Special Adviser to the Executive Director/UN Development Fund for Women (UNIFEM). Relevant publications include, inter alia, 'Rule of Law Strategies for Peace Operations' (International Peacekeeping: The Library of Essays in International Law (ed. Boris Kondoch), Ashgate Publishing, 2007), and the 'Report of the Conference on Gender Justice in Post-Conflict Situations' organized by UNIFEM and ILAC and submitted to the UN Security Council (UN Doc. S/2004/862), for which she was a principal drafter/editor for UNIFEM. 


\section{Introduction}

As the world approaches the $20^{\text {th }}$ anniversary of the UN Security Council's unanimous adoption of resolution 1325 on "Women and peace and security" on 31 October 2000, ${ }^{1}$ there will undoubtedly be many memories evoked of that milestone achievement and multiple reflections on the key drivers of such a feat. After all, it was the first time that the Security Council had ever adopted a resolution on this often-ignored topic and, moreover, one that, in the words of the UN Secretary-General, "marks a landmark in the recognition of women's contribution to the maintenance and promotion of peace and security and their specific needs and concerns in armed conflict and its aftermath, as well as the responsibilities of the international community to provide effective responses". ${ }^{2}$ In that resolution, the Security Council not only stressed "the importance of [women's] equal participation and full involvement in all efforts for the maintenance and promotion of peace and security, and the need to increase their role in decision-making with regard to conflict prevention and resolution", ${ }^{3}$ but also called for specific measures to betaken by all actorsinvolved to implement those bold commitments. That unprecedented resolution gave rise to what has become known as the "Women, Peace and Security agenda" and has led to the Council's adoption of nine other resolutions under that agenda item over the past twenty years. ${ }^{4}$ Unfortunately, persisting obstacles and gaps have prevented full implementation of that watershed political framework for promoting gender equality and strengthening women's participation and rights across the conflict prevention, conflict resolution, peacekeeping and peacebuilding continuum. This stark reality was most recently acknowledged by the Security Council in resolution 2493 (2019), as it recognized "the opportunity and need for far greater implementation of the women, peace and security agenda" and pointedly stated - as earlier voiced in resolution $2242(2015)$ - that it

remain [s] deeply concerned by persisting barriers to the full implementation of resolution 1325 (2000) and the frequent under-representation of women in many formal processes and bodies related to the maintenance

1 See UN Doc. S/RES/1325 (2000). The resolution was adopted during Namibia's presidency of the Council.

2 See "Report of the Secretary-General on women, peace and security", UN Doc. S/2002/1154 (UN Security Council, 16 October 2002), para. 3.

3 UN Doc. S/RES/1325 (2000), $5^{\text {th }}$ preambular para.

4 These include UN Security Council resolutions 1820 (2008), 1888 (2009), 1889 (2009), 1960 (2010), 2106 (2013), 2122 (2013), 2242 (2015), 2467 (2019), and 2493 (2019). See also UN Security Council resolution 2272 of 11 March 2016 (UN Doc. S/RES/2272 (2016)) addressing sexual exploitation and abuse by UN peacekeepers. 
of international peace and security, the relatively low number of women in senior positions in political, peace and security-related national, regional and international institutions, the lack of adequate gendersensitive humanitarian responses and support for women's leadership roles in these settings, insufficient financing for Women, Peace and Security, and the resulting detrimental impact on the maintenance of international peace and security. ${ }^{5}$

Among its calls, the Council urged Member States "to fully implement the provisions of all previous Security Council Resolutions pertaining to the Women, Peace and Security agenda and to reinforce their efforts in this regard", and requested the Secretary-General to ensure the full implementation of that agenda. ${ }^{6}$

Despite this very disappointing and checkered progress, both in scope and pace, various types of $20^{\text {th }}$ anniversary "commemorations" of the historic 1325 milestone will likely be organized by stakeholders across the globe, whether by the UN Security Council, Member States, UN Country Teams, civil society organizations, or by the many courageous women in conflict-affected countries who have not let the painful wounds of war extinguish their struggle to build a more secure, just and inclusive society - one that will address their dire needs and offer equal opportunities for both their daughters and sons. While it can be expected that the anniversary will trigger further analyses of the dismal implementation record of the resolution and what corrective action is required to seriously accelerate and steer future global efforts, there is apt to be less recollection of the factors that influenced the historical trajectory culminating in its adoption. One may argue that, instead of looking backward, it is far more important to focus on formulating an action blueprint for the future that will finally lead to substantial and comprehensive systemic change to execute the goals and calls for action in resolution 1325 and its successor resolutions. But, in developing that blueprint, it would be worthwhile to take account of a very unique event held in May 2000 - a Seminar in Windhoek, Namibia that was instrumental in fueling the momentum that led, only five months later, to the adoption of resolution 1325 , and particularly to take stock of the confluence of factors that contributed to the Seminar's momentous outcome: the ground-breaking "Windhoek Declaration" and the "Namibia Plan of Action

5 See Security Council resolution 2493 of 29 October 2019 (UN Doc. S/Res/2493 (2019)), $4^{\text {th }}$ preambular para. See also Security Council resolution 2242 of 13 October 2015 (UN Doc. S/RES/2242 (2015)), $15^{\text {th }}$ preambular para.

6 See UN Doc. S/RES/2493 (2019), paras. 1 and 9. 
on Mainstreaming a Gender Perspective in Multidimensional Peace Support Operations".7

The unquestionable influence of the "Seminar on Mainstreaming a Gender Perspective in Multidimensional Peace Support Operations", organized by the UN Department of Peacekeeping Operations' Lessons Learned Unit and hosted by the Namibian Government, and its two outcome documents was highlighted in the 2002 UN Study on Women, Peace and Security, which pointed out that " $t \mathrm{t}]$ he Windhoek Declaration was a critical step leading to the adoption of resolution 1325 (2000)". In addition, the 2002 UNIFEM-commissioned independent experts' assessment on Women, War, Peace conducted by Elisabeth Rehn and Ellen Johnson Sirleaf highlighted that "...it was not until 2000 that the UN thoroughly mapped the issues and elements needed to include gender in all aspects of multidimensional peace operations, in the Windhoek Declaration and Namibian Plan of Action", and that, soon after, in resolution 1325, "the Security Council confirmed the relevance of routinely including gender perspectives when executing peacekeeping missions". ${ }^{8}$ In order to reveal the ingredients and breadth of that influence, the article delves deeper by unpacking and scrutinizing the ways in which the visionary Windhoek Declaration and the more operational Namibia Plan of Action came into being and had such a critical impact on the adoption of resolution 1325 , and what specific factors ignited this exceptional outcome, including the role played by the host country.

In probing the significance of the Seminar's far-reaching impact, Section II of the article first examines the unique combination of factors that triggered such an outcome through the first-hand account of a Seminar speaker and Working Group member (the author) whose perspectives have also been shaped by more than three decades of UN peacekeeping and gender justice work. Through

7 The Permanent Representative of Namibia to the UN addressed a letter to the SecretaryGeneral of 12 July 2000 transmitting these two documents and asking to have the letter and its annexes distributed as a document of the General Assembly and of the Security Council (see UN Doc. A/55/138-S/2000/693 of 14July 2000).

8 For the UN Study, see UN Publication Sales No. E.o3.IV.1, ISBN 92-1-130222-6, para. 32; see also para. 245. This Study was initiated by the Secretary-General pursuant to Security Council resolution 1325 (see UN Doc. S/RES/1325 (2000), para. 16). Select findings and conclusions of the Study were presented in the "Report of the Secretary-General on women, peace and security" of 16 October 2002 (see UN Doc. S/2002/1154 (UN Security Council, 16 October 2002)); see also UN Doc. S/PV.4635, UN Doc. S/PV.4635 (Resumption 1), UN Doc. S/PV.4641, and the Statement of the Security Council President of 31 October 2002 (UN Doc. S/PRST/2002/32). For the UNIFEM-commissioned independent experts' assessment, see Women, War, Peace: The Independent Experts' Assessment on the Impact of Armed Conflict on Women and Women's Role in Peace-building (Progress of the World's Women 2002/Vol. 1, UNIFEM, New York, 2002, ISBN: 0-912917-66-o), Chap. 5, p. 65; this assessment is also referred to in UN Doc. S/PV.4635 and UN Doc. S/PV.4635 (Resumption 1). 
this prism, three key factors and the infectious effect of each are described, highlighting how the Seminar dynamics evolved over three intense days and providing granular insights into the interplay of inspiring speakers, deep-dive Working Group deliberations, and energetic and strategic plenary sessions.

The first influential factor focuses on what happened at the Seminar through a broader historical context which underscores its weighty significance. Namibia was considered a fitting host of such an unprecedented forum to discuss how to strengthen gender mainstreaming and gender balance in multidimensional peace support operations, which were acknowledged as woefully deficient at that juncture despite promising commitments made in the Beijing Platform for Action five years earlier. ${ }^{9}$ Windhoek was a symbolically powerful and compelling venue for the Seminar because it marked the $10^{\text {th }}$ anniversary of the UN Transition Assistance Group (UNTAG) that had ushered in Namibia's independence from apartheid South Africa, and, in addition, UNTAG represented a major evolutionary step for peacekeeping as the first deployed of the new generation of UN multi-component missions that further developed in the 199os. Boosting its distinction further, UNTAG was also considered a milestone for women as it was the first UN peacekeeping operation with a large substantive civilian component which offered significantly increased opportunities for women to participate, and was headed by a committed (male) SRSG whose deliberate efforts to recruit skilled women resulted in them filling some $40 \%$ of all substantive posts (including in important mid-level and senior positions). After UNTAG's closure, however, the substantial inroads that had been made for women seemed to be derailing in many of the subsequent multidimensional operations established in the 199os, and, adding to the downward spiral, major peacekeeping failures occurred with particularly horrific consequences for women and girls which triggered calls for their protection. As a result, there was a palpable concern and resolve among Seminar participants that they needed to urgently recommend concrete action to ensure that women's needs and rights would systematically be taken into account in planning and executing all future operations and that more women would be recruited so that the increased opportunities offered by multidimensional peace support missions would no longer be squandered.

The analysis describes the second influential factor as the product of three inter-locking elements that energized the Seminar and fostered candid and intense discourse among the participants and an action-driven approach that

9 See Report of the Fourth World Conference on Women, Beijing, China, 4-15 September 1995; UN Doc. A/CONF.177/20/Rev. 1 (UN General Assembly, 4-15 September 1995), Annex II, Chap. IV, Section E, paras. 131-149. The General Assembly endorsed the Beijing Declaration and the Platform for Action in its resolution 50/203 of 22 December 1995 (see UN Doc. A/REs/50/203 (1995), para. 2). 
ultimately led to its momentous outcome. The Seminar's highly-experienced and field-tested participants, who represented a broad range of crucial entities and partners (including from conflict-affected countries) and had extensive familiarity with intersecting peacekeeping and gender issues, enriched the level and nature of the plenary discussions and Working Group deliberations. Additionally, the Seminar was motivated by the impassioned presentations of bold women leaders (including two pioneering heads of peacekeeping missions) and the inspiring words of its Namibian hosts as well as by the vigorous plenary interventions during the opening day, which set expectations high from the outset for achieving concrete results. Another crucial element was the trajectory in which the Seminar progressed following the electrifying opening session, particularly once it was decided that the Working Groups would pivot in a more action-oriented direction than that initially planned by the organizers in order to produce the most effective outcome - a move which proved to be a decisive turning point.

Focusing on the Seminar's final stage, the third influential factor unveils the dynamics during the plenary discussion of the three Working Groups' reports that enabled the participants to decisively reach a consensus on the two outcome documents and a strategic approach for their transmittal to UN Headquarters. The participants' resolution of outstanding issues reflects the savvy strategic vision pursued and the laser-focused calculations made to ensure that the Windhoek Declaration and Namibia Plan of Action would be distributed to both the UN Security Council (that included Namibia) and the General Assembly (under Namibia's presidency) and recorded as an official document. Through their careful crafting of the Windhoek Declaration and its targeted recommendation, the participants aimed at generating pressure on the Secretary-General to ensure that appropriate follow-up measures would be taken to implement the Plan of Action.

Within this context, Section II then examines the impact that the Windhoek Seminar's two historic "blueprint" documents had on the text of Security Council resolution 1325 itself and how that impact was also visible in the many supportive statements of Member States during the Council's first open debate on "Women and peace and security". The analysis highlights that the Security Council, in its resolution 1325 , not only specifically referred to the Windhoek Declaration and the Namibia Plan of Action in recognizing the urgent need to mainstream a gender perspective in peacekeeping operations, but also called on the various actors involved to take a number of actions that largely correspond with those among the Plan of Action's 38 required measures for strengthening gender mainstreaming and gender balance in peace support operations. Based on a close review of the statements made during the open debate, the analysis further reveals that 8 of the 15 Council members and 12 
of the 26 non-Council members explicitly expressed support for the Windhoek Declaration and the Namibia Plan of Action and that many others conveyed support for various proposed measures in the Plan without specifically referring to it. Moreover, it brings to light that a number of Member States asserted that those measures should be taken into account in implementing the recommendations of the "Report of the Panel on United Nations Peace Operations" that had been issued earlier in August 2000. ${ }^{10}$

The closing reflections in Section III of the article offer a retrospect by the author of the very special dynamics that made the Windhoek Seminar so extraordinary and uplifting and caused it to ignite a "revolutionary" outcome. She shares how proud she felt, during her return flight to Kosovo, that the Seminar's participants, in the compelling setting of Namibia, had managed to collectively score such a victory for women by producing two groundbreaking documents and plotting a "transmission strategy" that would enlist the maximum support of the power brokers at UN Headquarters. While the momentum did indeed build in the UN Security Council, culminating in its adoption of resolution 1325 , the author laments that the progress made since that watershed Seminar and resolution in implementing gender mainstreaming throughout all stages of UN peace support operations has unfortunately been neither systematic nor sufficient. Influenced by what she witnessed on the ground during assignments to six peacekeeping operations over her career, that stark reality, she asserts, has perhaps been most anguishing for the countless number of marginalized and vulnerable women in conflictaffected countries across the globe who had hoped that their shattered lives would be uplifted by the promises made in those breakthrough documents two decades ago. In tilting the lens forward, she notes that those broken hopes, however, were re-ignited in October 2015 both by the issuance of a sobering Global Study on the Implementation of United Nations Security Council Resolution $1325^{11}$ that presented some 196 recommendations for action required to overcome the many gaps, and by the Security Council's sweeping calls for action in resolution $2242^{12}$ to improve implementation of its landmark women, peace and security agenda. Nevertheless, the extent of progress achieved over the past five years has continued to be alarmingly slow in many important areas.

10 The UN Secretary-General sent identical letters dated 21 August 2000 to the President of the General Assembly and the President of the Security Council with an enclosed letter dated 17 August 2000 from the Chairman of the Panel on United Nations Peace Operations to him which transmitted the Panel's report. See UN Doc. A/55/305-S/2000/809 (UN General Assembly and Security Council, 21 August 200o).

11 See Preventing Conflict, Transforming Justice, Securing the Peace: A Global Study on the Implementation of United Nations Security Council Resolution 1325 (UN Women, New York, 2015, ISBN: 978-o-692-54940-7), available at http://wps.unwomen.org/. 
Despite this troubling barometer reading, a rallying cry of hope is directed to all those who believe in the need for women to be fully involved as equal partners in all peace and security processes that this struggle can still be accelerated to achieve the results envisaged by the Seminar drafters of the Windhoek Declaration and the Namibia Plan of Action and by the Security Council members who unanimously voted to adopt resolution 1325 some twenty years ago. However, to prompt such a "course correction", the author maintains that strong and principled leadership by the UN Secretary-General is needed to spearhead and assume accountability for three major time-bound measures that would drive implementation action in order to achieve serious progress during this decade. But will this rallying cry be embraced during the upcoming $20^{\text {th }}$ anniversary commemorations of resolution 1325 to trigger another revolutionary outcome?

\section{The Far-Reaching Impact of the Windhoek Seminar and Its Outcome}

In reflecting on the significance of the Seminar organized by the Lessons Learned Unit of the UN Department of Peacekeeping Operations (DPKO) and hosted by the Namibian Government in Windhoek on 29-31 May 200o, I feel that it is important to acknowledge two rather remarkable aspects at the outset. First, the Seminar was able to produce, over only three days of presentations and discussions, two ground-breaking documents: the visionary "Windhoek Declaration" and the operational "Namibia Plan of Action on Mainstreaming a Gender Perspective in Multidimensional Peace Support Operations".13 And, second, this consequential outcome was a critical step in fueling the momentum that led - five months later - to the UN Security Council unanimously adopting landmark resolution 1325 on "Women and peace and security" on $3_{1}$ October 2000 under Namibia's presidency, ${ }^{14}$ which was the Council's first-ever resolution on this thematic topic.

In reviewing this trajectory, I will first offer a few of my own thoughts on the unique combination of factors that contributed to the Seminar's exceptional outcome, which will provide a context for then examining the impact that the Seminar's two "blueprint" documents had on the text of Security Council resolution 1325 and the related open debate. These thoughts are based on my direct impressions as a participant in the Seminar (and my notes and

13 See UN Doc. A/55/138-S/200o/693 of 14 July 2000, Annexes I and II.

14 UN Doc. S/RES/1325 (2000) of 31 October 2000. 
distributed documents), ${ }^{15}$ where I was a speaker at the session on "Gender Mainstreaming in Current Peace Support Operations" and a member of one of the Working Groups. At that time, I was serving as Chief of Staff to the Special Representative of the Secretary-General (SRSG) heading the United Nations Interim Administration Mission in Kosovo (UNMIK), which was established in June 1999 and included the first gender unit in a UN peacekeeping mission. I was really excited to participate in this Seminar on such a long-ignored issue that seemed so critical to address in view of what I had witnessed in the field during my assignments with UNMIK and four other peacekeeping operations over the previous 17 years, namely, the United Nations Interim Force in Lebanon (UNIFIL) (as the first woman Legal Adviser of any mission), the United Nations Transition Assistance Group (UNTAG) in Namibia, the United Nations Transitional Authority in Cambodia (UNTAC), and the United Nations Peace Forces (UN PF) headquartered in Zagreb, Croatia. Against this backdrop, I will elaborate on three key factors which I feel energized and fueled the Seminar to produce such an impactful Windhoek Declaration and Namibia Plan of Action.

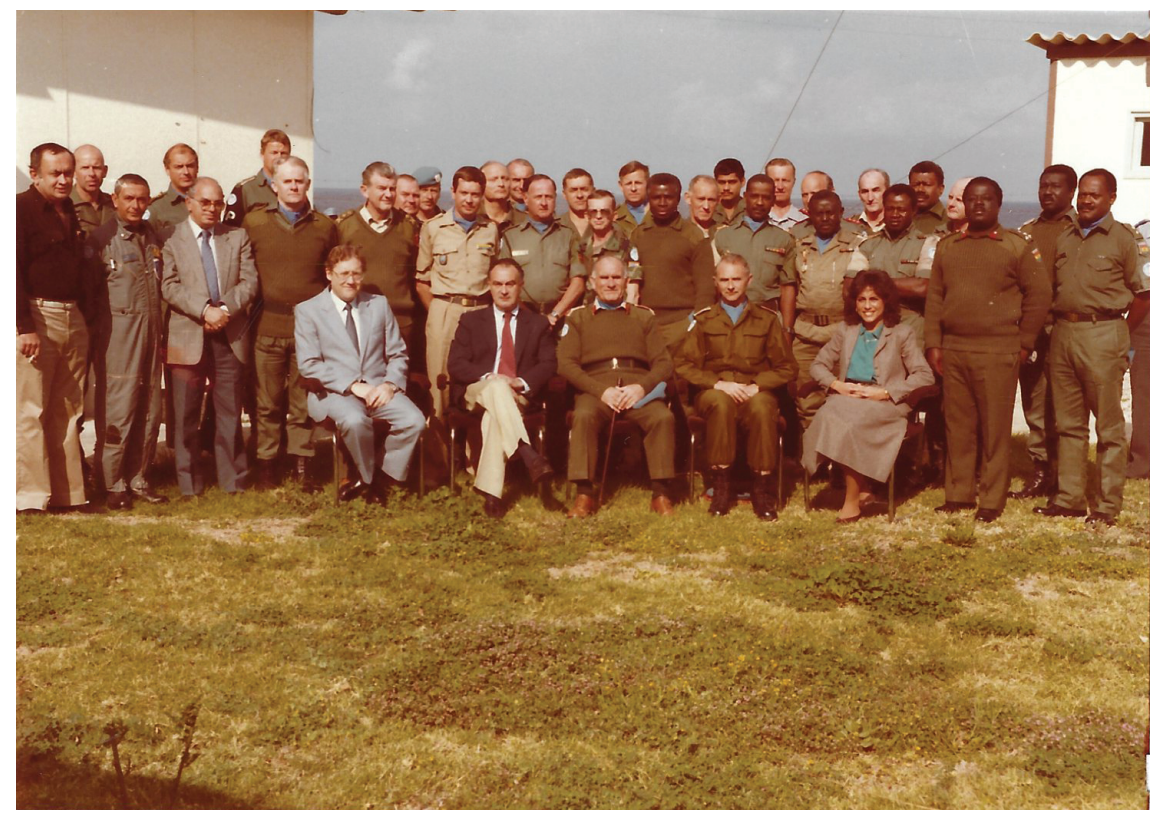

рното 1 UNifil Force Commander Gen. William Callaghan's Monthly Conference of top staff, with Legal Adviser Lahoud as the only woman (1984)

15 The distributed documents included the Seminar Programme and List of Participants, a few statements and presentations of speakers, and parts of the draft LLU Study with several case studies. My notes covered the Seminar presentations and discussions and our Working Group draft document. 
A. Key Factors that Contributed to the Windhoek Seminar's Momentous Outcome

(1) UNTAG's importance as a milestone for women and subsequent setbacks galvanized Seminar participants to recommend action to ensure that future mission opportunities for increasing women's participation would no longer be squandered

It is important to view what happened at the 2000 Windhoek Seminar within an even broader historical context in order to appreciate its weighty significance. As explained during my presentation to the Seminar, I found it very fitting that Namibia had been selected to host such an unprecedented lessons learned forum to discuss how to strengthen and sustain gender mainstreaming and gender balance in UN multidimensional peace support operations, which were generally acknowledged as woefully deficient at that juncture. After all, it was nearly five years after the Fourth World Conference on Women had adopted the "Beijing Platform for Action" on 15 September 1995 which, in its section on "Women and armed conflict", unequivocally stated:

In addressing armed or other conflicts, an active and visible policy of mainstreaming a gender perspective into all policies and programmes should be promoted so that before decisions are taken an analysis is made of the effects on women and men, respectively. ${ }^{16}$

In addition, the Beijing Platform for Action, in setting out required "Actions to be taken" by various stakeholders, had called on Governments and international and regional intergovernmental institutions to:

(a) Take action to promote equal participation of women and equal opportunities for women to participate in all forums and peace activities at all levels, particularly at the decision-making level, including in the United Nations Secretariat...;

(b) Integrate a gender perspective in the resolution of armed or other conflicts and foreign occupation and aim for gender balance when nominating or promoting candidates for judicial and other positions in all relevant international bodies,... as well as in other bodies related to the peaceful settlement of disputes;... ${ }^{17}$

16 See UN Doc. A/CONF.177/20/Rev. 1, Annex II, Chap. IV, Section E, para. 141.
17 Ibid., para. 142. 
Windhoek was a symbolically powerful and compelling venue for the Seminar for other momentous reasons, as it marked the tenth anniversary of UNTAG and of Namibia's independence from apartheid South Africa after a 24-year struggle. In addition, UNT AG represented a major evolutionary step for peacekeeping as it set a notable precedent as the first deployed of the UN's new generation of multi-component missions that further developed in the 199os, such as the United Nations Angola Verification Mission II (UnAVEm II), the United Nations Transitional Authority in Cambodia (UnTAC), the United Nations Protection Force (UNPROFOR) in the former Yugoslavia, and the United Nations Operation in Mozambique (ONUMOZ). In contrast to previous decades of traditional peacekeeping missions staffed by mostly male military personnel to monitor ceasefires or the implementation of peace agreements, UNTAG pioneered the transition to expanded multidimensional missions that increasingly had a range of components in addition to military contingents, such as civilian police, political affairs, civil affairs, electoral, rule of law, human rights, humanitarian relief, reconstruction and public information elements, all of which had crucial consequences for women and men of the host country.

As the first UN peacekeeping operation to include a large substantive civilian component (but no gender unit), UNTAG's establishment in April 1989 was really considered as a milestone for women as it offered significantly increased opportunities for them to participate in substantive positions in the Mission's various offices and to carry out mandated activities to provide much-needed support for Namibia's oppressed women and men - both crucial if the UN's goals regarding gender equality and non-discrimination were to be realized. Largely due to the committed and deliberate efforts of UNTAG SRSG Martti Ahtisaari to recruit skilled women for the Mission, the number of female staff amounted to some $40 \%$ of all substantive posts, including in mid-level and some important senior positions (e.g., District Centre Heads, Civilian Police Liaison/Director, Deputy Legal Adviser). In fact, Mr. Ahtisaari, when interviewed in 1999, recalled such efforts in explaining:

The presence of women didn't occur haphazardly. We quite simply interviewed as widely as possible and selected the best....Women carrying out professional functions in a very macho and male dominated society had a great impact. UNTAG probably left an indelible mark on Namibian society by facilitating attitudinal changes regarding the so-called 'proper role' of women in society. 18 
Women staff, like many men, found UNTAG to be an incredibly fulfilling and worthwhile experience, ${ }^{19}$ and, even more importantly, were also widely embraced and respected by the Namibian population, particularly as the Mission - within a one-year timetable - successfully ushered in their longawaited independence from the chokehold of South African occupation. This was poignantly voiced by Hon. Gabriel Shihepo, Namibia's Deputy Minister of Foreign Affairs, Information and Broadcasting, in his Official Opening statement to the Seminar:

We in Namibia harbour positive feelings towards the peacekeeping operations of the United Nations. Our peaceful transition to independence in 1990 was largely due to the successful operations of the United Nations Transition Assistance Group. UNTAG monitored the implementation of Resolution 435, which led to the first ever democratic elections in this country, allowing Namibians to shed the yoke of apartheid and restoring the dignity and human rights of the majority of the Namibian population. The 1989-1990 United Nations Peacekeeping Operation in Namibia is one of the glorious success stories of UN peacekeeping operations.

However, after the closure of UNTAG in March 1990, the substantial inroads that had been made for women in that Mission under the leadership of SRSG Ahtisaari (who later became President of Finland and a Nobel Peace Prize Laureate) seemed to be derailing. In many of the subsequent multi-component missions established in the 199os, the numbers of women recruited for substantive functions and at higher levels were often disappointingly low. As just one example, in the United Nations Transitional Authority in Cambodia (UNTAC), one of the largest multidimensional peacekeeping operations that was established in February 1992 with seven substantive components and an authorized strength of 1227 international civilian staff, no woman was appointed at the level of Director or above despite the range of positions at those levels that existed throughout the Mission's structure. ${ }^{20}$ In addition, the 199os had

19 When interviewed in 1999 on my service in UNTAG and in earlier peacekeeping missions, I emphasized why it was such a fulfilling experience in stating: "Mission service is the best thing I've come across in life. The lack of hierarchy in working relationships, the close integration of civilian and military staff, the 'can do' morale and the sheer uplifting experience of making a difference for the population - all these make it an opportunity not to be missed. It's the best of what the UN can offer in every respect." (Ibid., p. 19)

20 The authorized 1227 international civilian staff posts included the following fifteen at the top levels: one Under-Secretary-General (USG), two Assistant Secretaries-General (ASGs) and twelve Directors (D-2s). See "Report of the Secretary-General on the Financing of the United Nations Transitional Authority in Cambodia", UN Doc. A/47/733 (UN General Assembly, 27 November 1992), pp. 41, 88-89, 190-191 (Annex VIII); the Addendum to 
seen some major peacekeeping failures with horrific consequences, such as in Somalia, Rwanda and Bosnia, where civilian women and girls were often specifically targeted by armed elements because rape and sexual violence continued to be used as weapons of war, which generated much outrage and calls for their protection to avert further violence.

For all of these reasons, at the time that the Windhoek Seminar was convened, there was a palpable concern and resolve among the 62 participants $5^{1}$ of whom were women - to tackle the longstanding necessity to ensure that women's needs and rights would systematically be taken into account in the planning and execution of all future UN peace support operations and that more women would be recruited, including for senior and decision-making positions, to be able to fully participate and make critical contributions in those missions. The Seminar participants, who included some who had served in UNTAG and its UN agency partners, did not want the inroads made by women in the UNTAG operation to be reversed, and were enthusiastically determined that the Seminar must produce practical and concrete results to try to get the momentum back on track. Simply put, participants felt that it was critical to recommend concrete measures that would make the UN and Member States accountable, in the future, for ensuring that the increased opportunities offered by the new generation of multidimensional peace support missions, where women could potentially assume so many substantive roles and provide a positive example of leadership potential to communities rebuilding their war-torn societies, would no longer be squandered.

\section{The candid and focused discussions among Seminar participants led to the adoption of a bold action-oriented approach for strengthening gender mainstreaming in multidimensional peace support missions}

Over my 33-year UN career attending numerous conferences on topics relating to peacekeeping, gender equality, and the "Women, Peace and Security agenda", I would say that the Windhoek Seminar generated frank, bold and action-oriented discussions and brainstorming among participants - both during plenary and Working Group sessions - of an intensity and level that I had never experienced before. I feel that three inter-locking elements fostered the candid and focused discourse and action-driven approach that evolved

the Report, UN Doc. A/47/733/Add. 1 (UN General Assembly, 27 July 1993), pp. 68-70 (Annex v) and pp. 117-118 (Annex XIX); and UN General Assembly resolution 47/209 on "Financing of the United Nations Transitional Authority in Cambodia", UN Doc. A/RES/47/209 of 24 March 1993. 
over the Seminar's three long days (and nights) and ultimately led to such a momentous outcome, with the adoption of two ground-breaking documents at its conclusion as well as an agreed strategic approach for going forward that aimed to captivate the attention of the relevant actors at UN Headquarters and generate support and action for implementation.

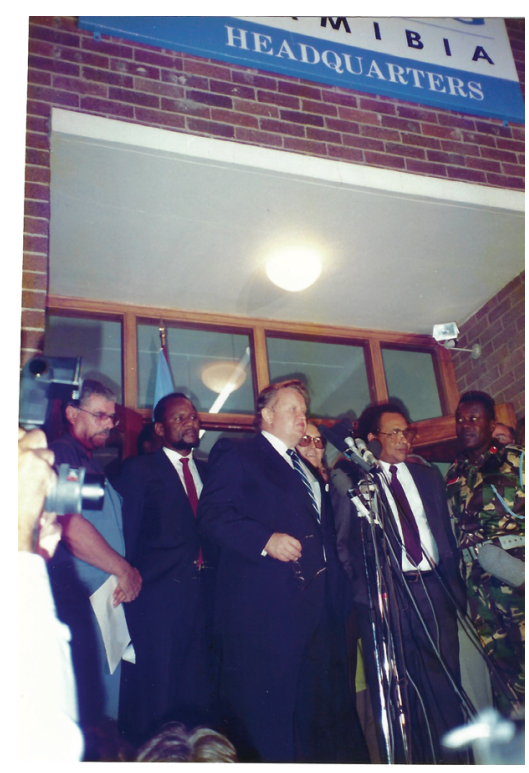

PHOTO 2

UNTAG SRSG Martti Ahtisaari announcing the results of the "free and fair" election for the first Constituent Assembly of Namibia (November 1989)

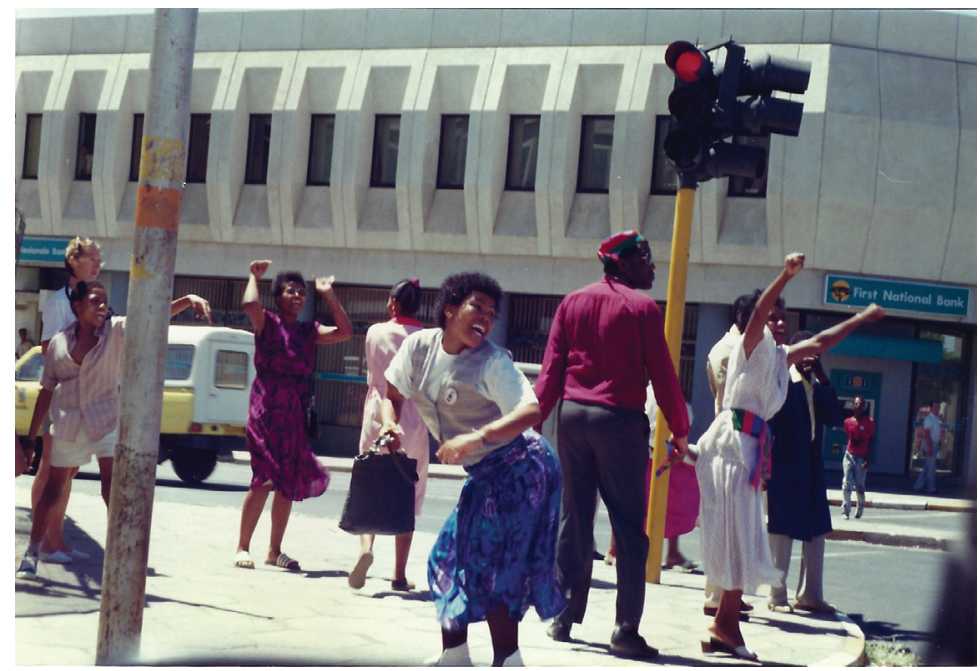

Pното 3 Namibian women dancing on the streets of Windhoek during public celebrations of the elections (November 1989) 


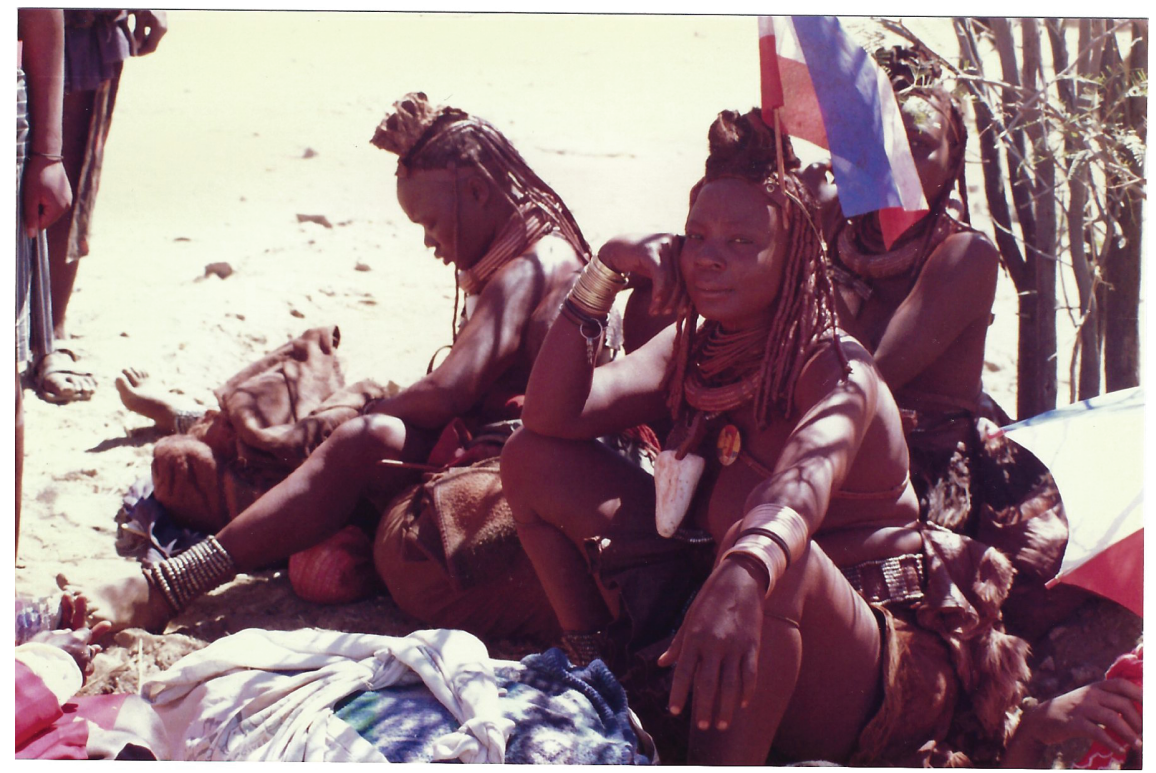

Рното 4 Himba women from a village near Opuwo in northern Namibia (1989)

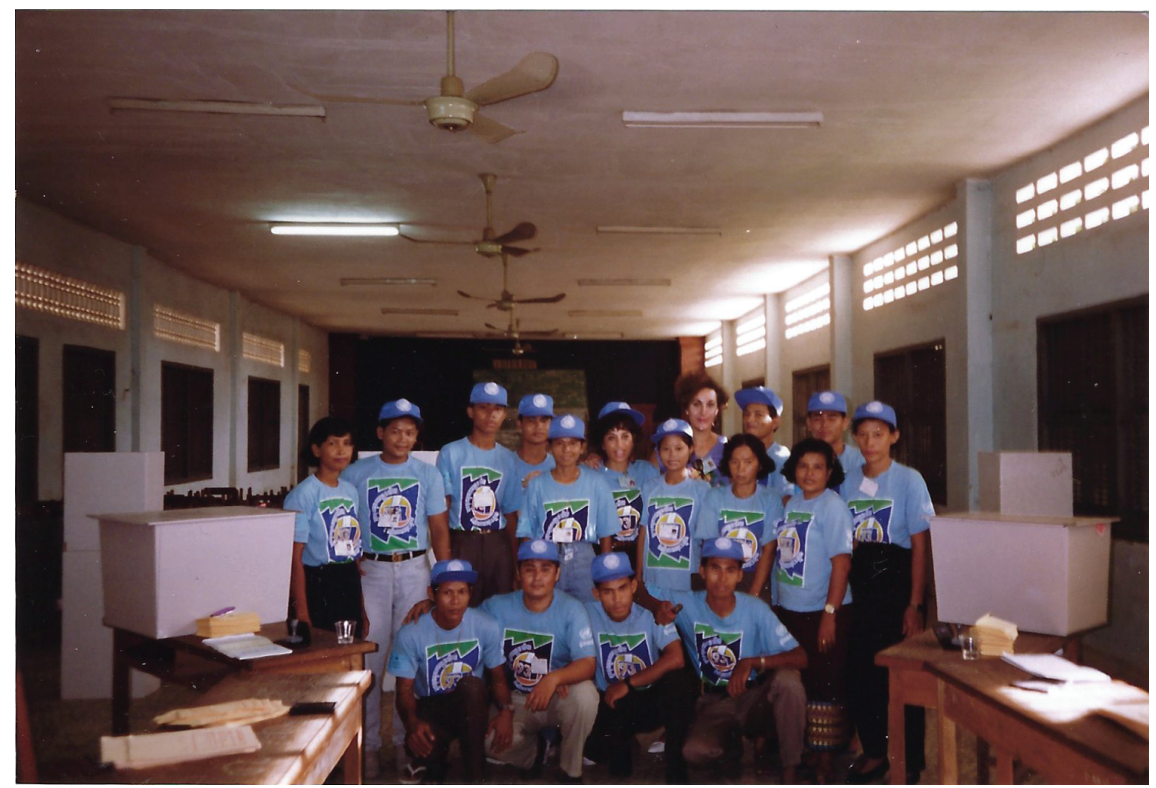

рното 5 Untac Election Polling Team Leader Lahoud and Cambodian polling officers at their polling station in Phnom Penh for UnTAC-organized Constituent Assembly elections (May 1993) 
As a first key element, the Seminar's 62 participants ( 51 women) represented a broad range of crucial entities and partners, possessed extensive knowledge and hands-on experience in dealing with peacekeeping and gender matters (including in top leadership positions), and were from diverse geographical areas that included a number of conflict-affected countries - all of which enriched the level and nature of the plenary discussions and Working Group deliberations. It was not only beneficial but invaluable to have so many participants from various key entities who had in-depth familiarity with intersecting peacekeeping and gender issues as well as with the complex operational realities in mission settings. In addition, participants from conflictaffected countries, including some that had hosted UN peacekeeping operations, candidly shared the perspectives of national stakeholders, including of oftenignored women on the ground. The latter was very important given that the Seminar (and the broader DPKO/LLU Study) also sought to consider the effects and consequences of the presence of a UN peacekeeping operation on the population of the host country, particularly its women. Underscoring the Seminar's uniquely diverse composition, the 62 participants (11 Namibians) included:

(a) current and former senior UN officials with substantial experience in handling peacekeeping matters at UN Headquarters and in field missions (including, e.g., four former SRSGs/Force Commanders who headed missions; programme managers from relevant UN entities (DPKO, DPA, OCHA, UNHCR, DDA, UNOV, UNDP and UNICEF); and former UNTAG personnel);

(b) current and former diplomats and officials from Ministries (Foreign Affairs, Defence, Women Affairs), Embassies, Permanent Missions to the UN, parliaments, and development agencies of various Member States;

(c) National Military Advisers and Police Inspectors;

(d) Directors of regional and international peacekeeping training centres;

(e) non-governmental organizations; and

(f) professors and researchers from leading academic institutions and research institutes on peace and conflict resolution.

A second instrumental element was that the Seminar, for the entire three-day duration, was energized and motivated by the impassioned and provocative presentations of outstanding women leaders, the galvanizing words of our Namibian hosts, and the vigorous plenary interventions during the opening day, which set expectations high for achieving concrete results. This momentum 
began, on 29 May, with our Namibian hosts: Hon. Netumbo NandiNdaitwah (Minister for Women Affairs and Child Welfare), who welcomed the participants, and Hon. Gabriel Shihepo (Deputy Minister of Foreign Affairs, Information and Broadcasting), who gave a rousing Official Opening statement. Fueling that momentum further, the two women who had served as pioneering female SRSGS of UN peacekeeping missions - Dame Margaret Anstee (former SRSG/UNAVEM II in 1992-1993) and Mrs. Elisabeth Rehn (former SRSG/UNMIBH in 1998-1999) - played inspiring lead roles from the start and throughout the entire Seminar. Dame Anstee served as the Seminar's Chairperson (in place of the Chief of DP KO's LLU who could not attend) and gave the Keynote Address, and Mrs. Rehn was the Discussant during the session on "Gender Mainstreaming in Current Peace Support Operations" and a vital Working Group Chairperson (with whom I collaborated until the wee hours). During discussions over the three days, each of them were straightforward and bold in highlighting obstacles faced and lessons learned on the ground in leading missions in Angola and Bosnia and Herzegovina respectively, and in recommending specific actions that they felt were urgently needed to propel progress on gender mainstreaming and gender balance in missions. Their exceptional candor was not only refreshing and stimulating but also had an emboldening effect on the participants.

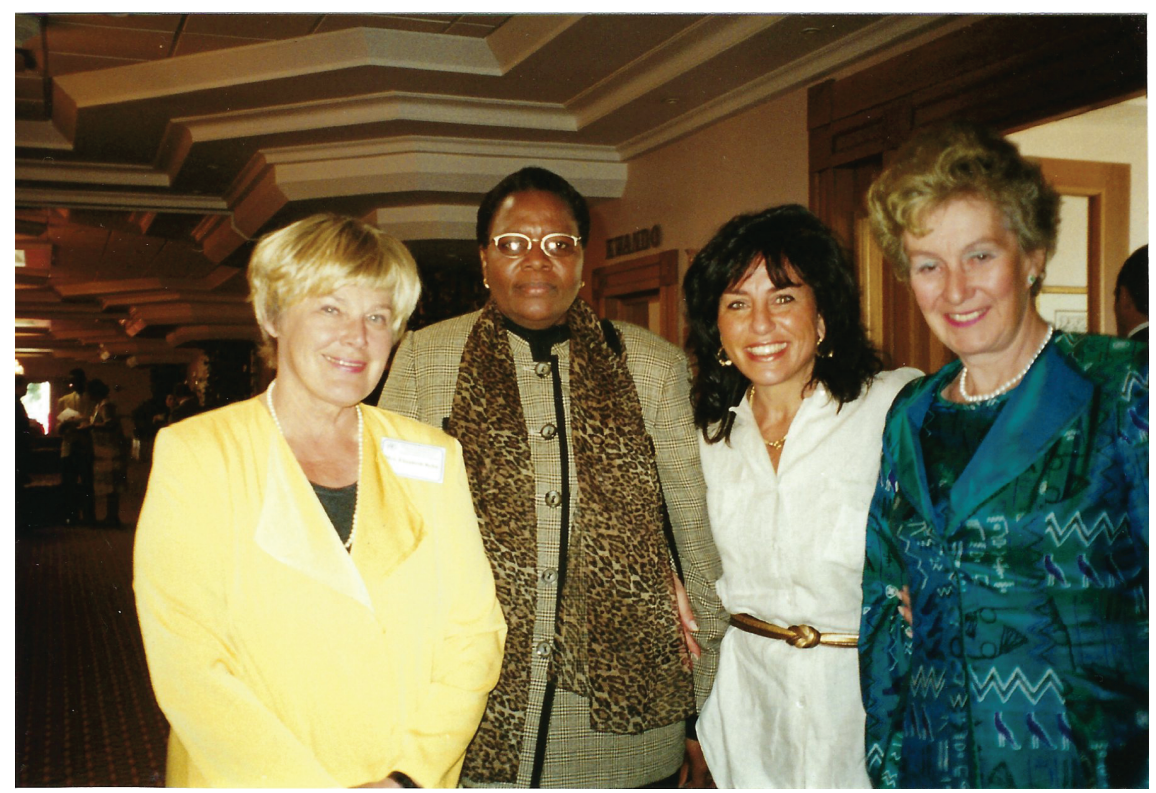

рното 6 Windhoek Seminar held in May 2000 (Mrs. Elisabeth Rehn, Hon. Netumbo NandiNdaitwah, Ms. Nina Lahoud, and Chairperson Dame Margaret Anstee: l to r) 
In her Keynote Address during the opening session, Dame Anstee candidly shared the high expectations and extreme pressures that she faced as the very first female SRSG to be appointed to head a UN peacekeeping operation simply because she was a woman, and how it made it all the more important for her to succeed in that role. This was particularly revealing and striking to me as it was coming from someone who had served at the United Nations for over four decades (1952-1993) and was the first woman to rise to the rank of an UnderSecretary-General in 1987. After elaborating on her experience, including some telling moments and challenges in leading UnAvem II in Angola, Dame Anstee then shared some of her recommendations for strengthening gender mainstreaming in missions. She presented five priority requirements: (1) the need to involve more women in planning for UN peace support operations and in peace negotiations, (2) the need for more women to be appointed as SRSGS (and to be encouraged to serve in that position), and for Member States to put forth more senior women as candidates, (3) the need to enhance the role of women in peace support operations as they were increasingly being mandated with a peacebuilding role involving civil society, including for women to be at the peace table at the outset and every stage thereafter, (4) the need for institutions to enhance the role of women, and (5) the need to look at ways to get greater involvement of women at all levels of peace negotiations and peace processes, including "involving local women from the outset on the peace table and not just for picking up the pieces". Related to these recommendations, Dame Anstee pointed out that there was a list of senior women available to serve as SRSGs that had been established by a group of female Permanent Representatives to the UN, and also that more women needed to volunteer to serve in field missions. She further emphasized the importance of regular monitoring of peace support missions, and of obtaining "comparative results".

The Official Opening was then made by Hon. Gabriel Shihepo, Namibia's Deputy Minister of Foreign Affairs, Information and Broadcasting, who gave a stirring speech which was all the more moving coming from a man in that position. He emphasized "the conviction of the Namibian Government for the need to mainstream gender perspectives in future UN peacekeeping operations", and proudly pointed out that, since its inception, the Government "has been a vocal advocate of gender mainstreaming in all spheres of life in order to improve the lives of all our citizens and to ensure sustainable socio-economic development to the benefit of the nation as a whole". He highlighted that "[g]ender equality is entrenched as one of the fundamental human rights in our constitution", and that "[g]ender mainstreaming received a further boost in Namibia when the National Gender Policy and Gender Plan of Action was launched in 1997 and since then, [the] Government has done everything in its power to redress the inequalities between women and men in the Namibian 
society". Asserting that it was incumbent upon "the new generation of leaders in the $21^{\text {st }}$ century to break down ancient barriers that are determining the traditional roles of men and women", Minister Shihepo set the bar high for the Seminar in appealing to participants to demonstrate the courage to act and produce concrete recommendations in order to make progress on gender mainstreaming in peace support operations and open up opportunities for women which had long been denied to them:

Unless we demonstrate the courage and commitment to act insofar as gender mainstreaming in peace support operations are concerned, we shall not make any progress. Unless we give women the opportunity to assume leadership and management positions, to engage in strenuous physical activities or to show their mettle in peace negotiations, we will while away the hours around conference tables wondering what would be the appropriate thing to do. Unless men accept that women have attributes that can contribute to peace, development, growth and stability, we will not make progress....

I am told that the objectives of this seminar are to determine the relevance and dimensions of gender in peacekeeping operations, the effectiveness of women in such operations, to increase the number of women in multidimensional operations at all levels, to assess the impact of peacekeepers on the local populations and to review the contributions of local women to peacekeeping and peace support activities.

The mere fact that you are gathered here to deliberate on these issues, is a positive and commendable signal that action is being taken to ensure that women assume their rightful place in shaping the future and destinies of nations and the world at large. I trust that once these issues have been debated, prompt action would be taken and policy guidelines drafted to ensure that both men and women are given the chance to contribute to the promotion of global peace, reconstruction and stability.

From the list of participants in this seminar it is clear that experts with first-hand experience of the role that women can play in peacekeeping operations will enrich your discussions with their contributions. I hope that this seminar will produce clear-cut recommendations on mainstreaming a gender perspective in future multidimensional peacekeeping operations and I trust that the Lessons Learned Unit of the 
Department of Peacekeeping Operations will implement those recommendations forthwith.

A third key element relates to the trajectory in which the Seminar's discussions and Working Groups progressed following the electrifying opening session on 29 May, particularly once it was decided that the Working Groups would pivot in a different direction than initially intended in order to produce the most effective outcome. To understand this development, it is important to recall that the Seminar was organized by DPKO's Lessons Learned Unit (LLU) as part of an ongoing three-year Study project on "Mainstreaming a Gender Perspective in Multidimensional Peace Operations", which also involved case studies focusing on four UN multidimensional missions (in Namibia, Cambodia, El Salvador, and Bosnia and Herzegovina) and on the civilian UN Observer Mission in South Africa (UNOMSA). The LLU's original intention was to obtain input from the Seminar participants primarily on the draft Study report's section entitled "Checklist and Suggestions", grouped under six areas of primary concern, which aimed to strengthen implementation of gender mainstreaming and gender balance in multidimensional peace support operations.

To steer discussions in that direction, the second session of the morning of 29 May featured three speakers who gave addresses that focused on the ongoing LLU Study and draft report: (1) Professor Peter Wallensteen of the Department of Peace and Conflict Research at Uppsala University, who had assisted in preparing the draft Study and in providing researchers to undertake some of the case studies, (2) General Emmanuel Erskine/Llu Senior Consultant (former UNTSO Chief of Staff/1976-1978 and 1981-1986 and first UNIFIL Force Commander/1978-1981), who delivered an address on behalf of Mr. Leonard Kapungu/Chief of the LLU, and (3) Professor Judith Stiehm/LLU Consultant (Department of Political Science/Florida International University), who made a presentation on the Study's "Draft Principles and Guidelines for Mainstreaming a Gender Perspective in Multidimensional Peace Support Operations". During the engaging discussions that followed, a major issue emerged among participants regarding whether the primary focus of the Seminar and Working Groups should be - as LLU had planned - on reviewing the draft Study report's "Checklist and Suggestions" or, instead, on formulating more action-oriented directives in order to produce an end product that would galvanize urgent action to be taken by all concerned. As the Seminar discussions and Working Group deliberations progressed, it was clear that the latter approach was on its way to prevail. 
After the lunch break, there were two afternoon sessions with speakers, followed by plenary discussions, and then a final session on the announcement of the Working Groups. The first afternoon session was on "Gender Mainstreaming in Current Peace Support Operations" with former UNMIBH SRSG Elisabeth Rehn as the Discussant, who had been the third female SRSG to be appointed in the UN's history in 1998 (after serving as Finland's first female Minister of Defence in 1990-1994) and whom I had long admired as a principled and outspoken leader. In view of the Seminar's theme, the session gave prominence to the two UN multidimensional peacekeeping missions that had each been vested with unprecedented executive governing authority and included the first-ever gender units in their structures: the United Nations Interim Administration Mission in Kosovo (UNMIK) established on 10 June $1999^{21}$ and the United Nations Transitional Administration in East Timor (UntAet) established on 25 October $1999 .^{22}$

As I was then serving as Chief of Staff to UNMIK SRSG Bernard Kouchner (who later became French Minister of Foreign and European Affairs), I gave a presentation entitled “UNMIK's Gender Challenge: Increasing the Levels of Women in Positions of Leadership and Governance in the Shared Administration of Kosovo". Given that UNMIK was the first mission in which the UN was mandated to form an interim administration and held executive authority over judicial, legislative and other civil activities in the territory, I focused on the approaches taken by the Mission's leadership to seize on this unique opportunity to actively promote increased women's representation in positions of leadership and governance in Kosovo as well as on some of the constraints encountered. As SRSG Kouchner had made this a priority for the year 2000, I shared the progress achieved to date in the appointment of women in the new central and municipal structures of the interim shared administration for Kosovo, which reflected that women were starting to regain a prominent role though the statistics were not yet nearly high enough. From a more personal perspective, I also shared how elated I was to be in Windhoek again almost ten years after having served as the UNTAG Deputy Legal Adviser, and that I found it to be in stark contrast to the city that I had left in June 1990 which gave me real hope that the UN "transition mission" in Kosovo could ultimately be as effective as that carried out in Namibia.

\footnotetext{
21 See UN Security Council resolution 1244 of 10 June 1999 (UN Doc. S/RES/1244 (1999)).

22 See UN Security Council resolution 1272 of 25 October 1999 (UN Doc. S/RES/1272 (1999)).
} 
To provide another perspective, Ms. Roma Bhattacharjea, Gender Policy Officer/UNMIк Office of Gender Affairs (within the Office of the SRSG), then gave a presentation entitled "Setting the Stage: Lessons Learnt from the Experience of the Office of Gender Affairs in Kosovo", which focused on progress and challenges faced in operationalizing that Office, undertaking strategies and actions to address the priority gender issues that had been identified, and fostering a process for gender mainstreaming throughout the Mission's unique fourpillar structure. To provide insights on the experience in UnTAET, Ms. Sherrill Whittington, Chief of the Gender Affairs Unit (within the Office of the Deputy SRSG for Governance and Public Administration), gave a presentation entitled "UnTAET: Gender Mainstreaming" which elaborated on the strategies and mechanisms pursued in the context of the Mission's mandated tasks and executive authority powers for the administration of East Timor during its transition to independence as well as across all policies and programmes within the governance and public administration and the humanitarian assistance and emergency rehabilitation components.

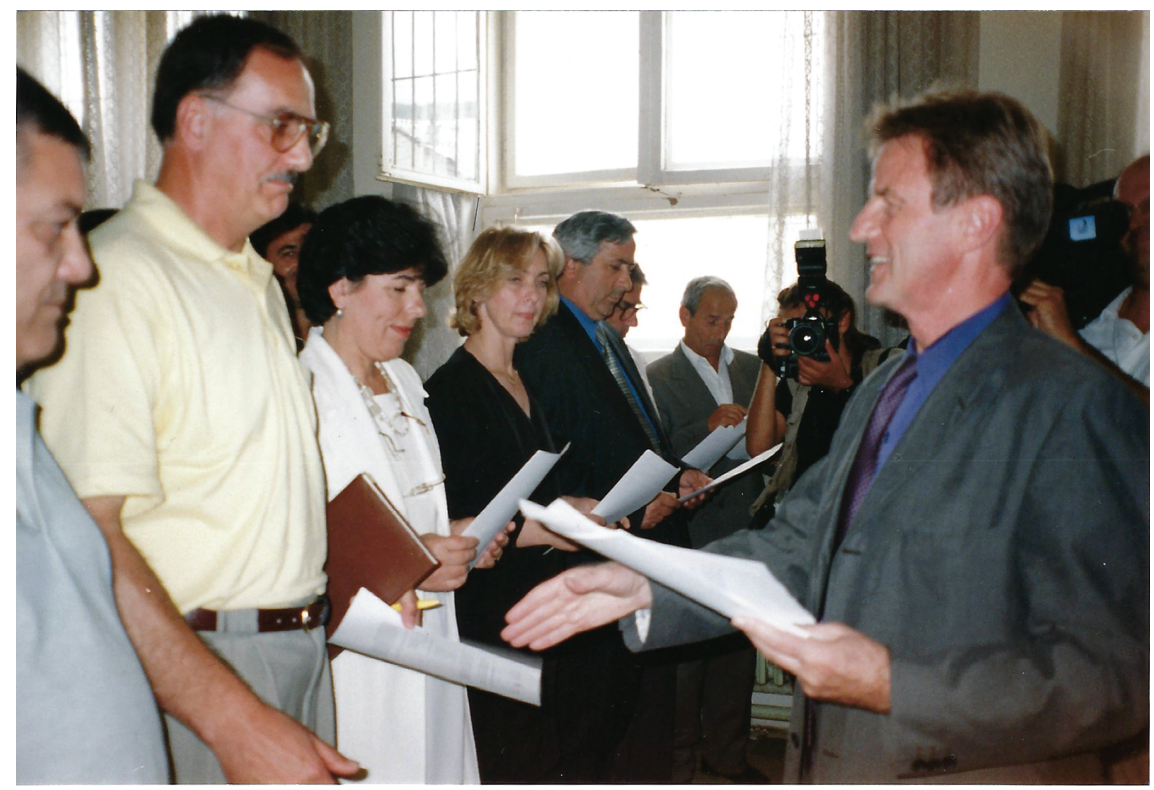

Pното 7 UNMIK SRSG Bernard Kouchner swearing in newly-appointed Kosovo judges, including women (2000) 


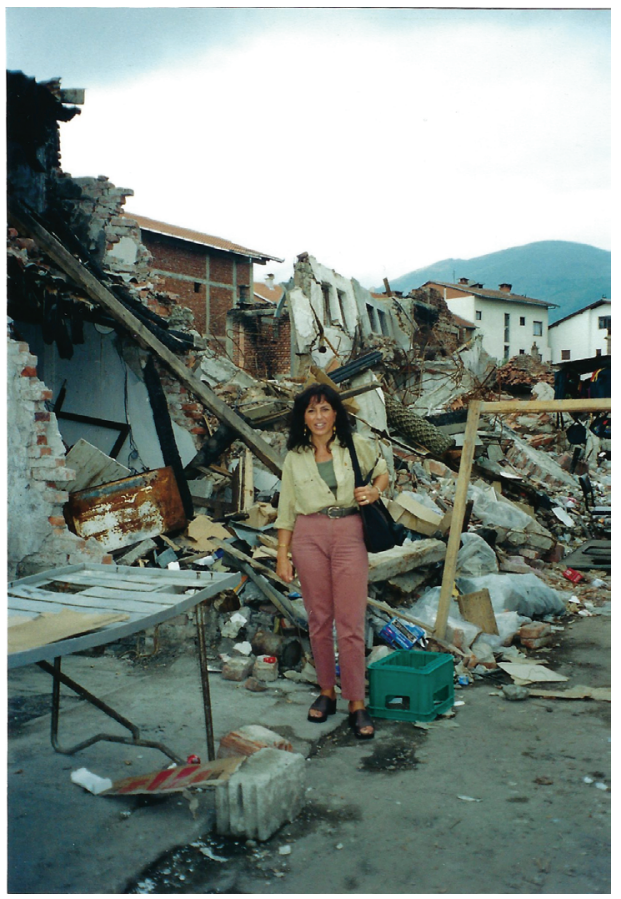

Pното 8

Lahoud amidst bombed buildings in Prizren, Kosovo (1999)

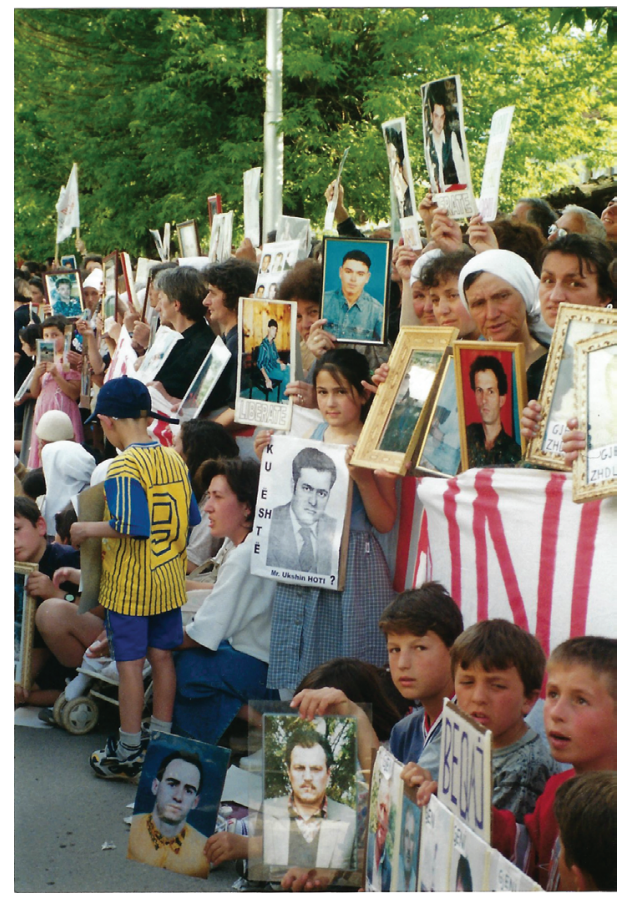

Рното 9

"Mothers of the Missing" demonstrating in Djakovica, Kosovo during a UN Security Council visit (April 200o) 


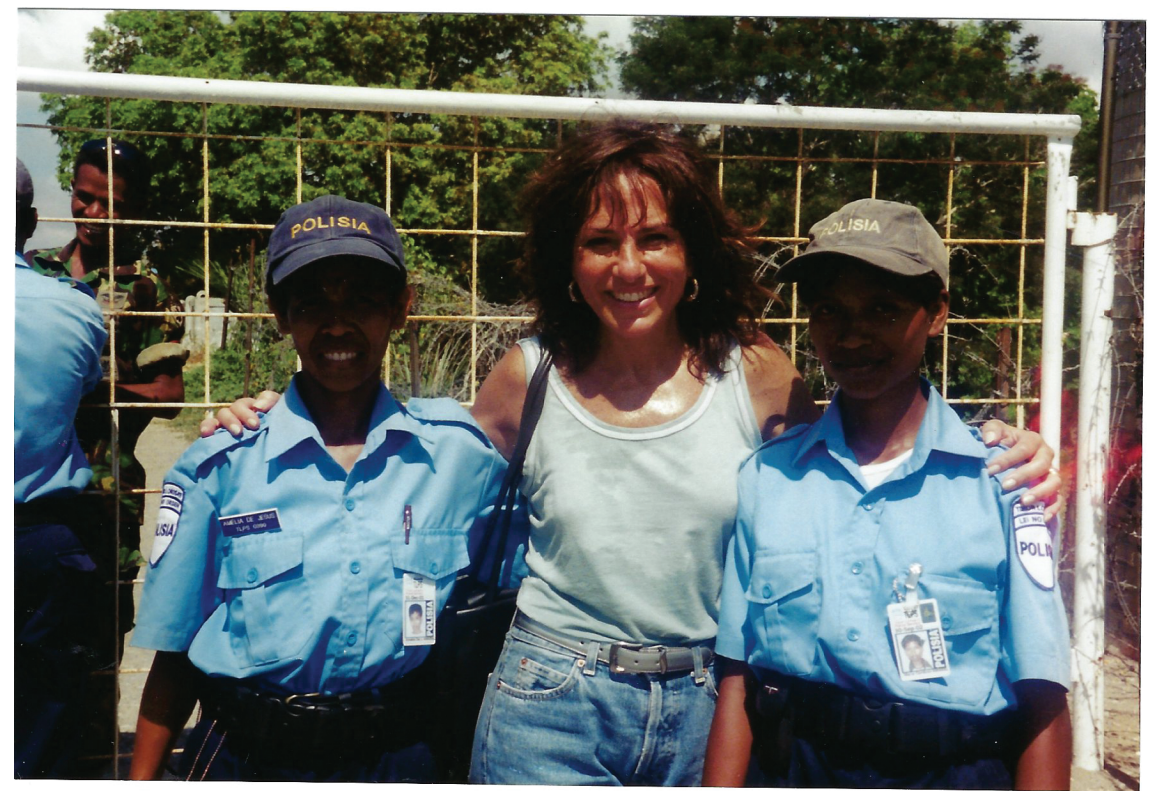

Рното 10 Lahoud with two UnTAET-trained Timorese women police officers working at the border crossing with West Timor (2001)

Following these presentations on UNMIK and UnTAET, Mrs. Rehn, ${ }^{23}$ as Discussant, contrasted her earlier experience in serving as a female sRSG heading UNMIBH in Bosnia and Herzegovina in 1998-1999, where she did not have the support of a gender unit. In her usual straightforward manner, she elaborated on her persistent efforts to increase gender mainstreaming and the number of women staff across the mission (particularly at the professional level) as well as on the challenges confronted, including as regards the conduct of the more than 2000 police officers within UNMIBH's civilian police component (the "UN International Police Task Force") vis-à-vis the local women. She highlighted the need for a stronger Code of Conduct for UN civilian police, as well as the "need to get better cooperation with UN agencies and bodies". She also underscored that "rule of law is extremely important and women need to believe that their complaints will be heard in a proper judicial forum". It was especially striking (and emotional for me) when, from a more human angle, she emphasized that, with all the pressures faced by the population such as the many missing persons and the mass graves, "it

23 Mrs. Rehn, who also served as a Working Group Chairperson, agreed with the account presented by the author in this article in electronic and phone communications with her. 
was important for the Mission to pay attention to the human problems of the people" and that there was a "need to reach grass-roots level interaction with women as they are aware of all problems". In provocatively asking "What does it require to have a human face?", she explained that she "had broken the rules by not accepting security around her when interacting with the local people", who saw her "as a bit of a mother who will understand human problems so it was very important to be just with them". She passionately asserted that "this is one way to make the Head of Mission more forthcoming to people and to be more human which is what the UN needs to be". On leadership, she also bluntly stated that "[i]f we want women to participate in their own societies, the UN should serve as a role model" and cautioned that "[y]ou have to keep yourself as a woman to serve as a leader and don't try to become a man", which was especially poignant given her former role as Finland's Minister of Defence. While listening to her, I was thinking to myself how those comments reflected the unique combination of attributes that made Mrs. Rehn a very special and courageous woman leader and compassionate human being - which is how I still feel today after collaborating with her over the years.

During the second afternoon session, Ms. Wanjiru Kihoro, Director and Founder of Abantu for Development (an NGO seeking to empower and train African women for leadership positions and address gender inequalities), gave a presentation on "Gender Implications of Peacekeeping and Reconstruction in Africa" which summarized the recommendations of a seminar held as part of a UNIFEM- and SIDA-funded study. She explained that, for the first time, the seminar brought together military personnel, civilians and police to discuss a framework and actions for integrating a gender perspective in peacekeeping and reconstruction in Africa, and that she felt it was important to include "social issues-related support" within that framework. She further explained that she had been asked to present the recommendations at the Windhoek Seminar for feedback and to then discuss them at a forum to be held during the UN General Assembly's Special Session on "Women 2000: Gender Equality, Development and Peace for the Twenty-First Century" $($ Beijing +5$)$ in June. The recommendations, which included, among others, that there should be a gender unit in the United Nations Organization Mission in the Democratic Republic of the Congo (MONUC) that had been recently established in November 1999, and that women peacekeepers should be deployed at all levels of a peacekeeping operation, were consistent with many that had been made by earlier speakers and participants.

These two afternoon sessions on 29 May led to very animated plenary discussions focusing on the many issues and challenges that had been raised in 
the presentations. Most of the interventions by participants related to the following: the functioning of the unprecedented gender units in UNMIK and UNTAET and the extent of their interaction and exchange of lessons learned; the degree of cooperation between each gender unit and relevant $\mathrm{UN}$ agencies in theatre; the advantages to be gained if higher-level and larger-staffed gender units were established in peace support missions (as initially proposed for UNMIK and UNTAET but later downgraded); the UN eligibility criteria for selection of Force Commanders and other high-ranking military positions which often preempt women from qualifying, such as command experience; the role of women's non-governmental organizations and how they might coordinate on a gender approach with a peacekeeping mission; possible regional approaches to gender mainstreaming with the support of regional organizations, such as the Organization of African Unity; how media could be used to influence women and what feedback had been given; and the handling of obstacles to gender mainstreaming initiatives relating to attitudes of local elements within the host country.

During the final session of the afternoon of 29 May on "Announcement of Working Groups", the Seminar pivoted to a discussion of the three Working Groups to be formed and the designated Chairpersons and Rapporteurs, and how they would proceed throughout the next day to be able to present their reports on the morning of $3^{1}$ May (the final day) for discussion and consolidation. As mentioned earlier, the LLu's original intention was to establish three Working Groups (listed in the Seminar Programme) to review the draft Study report's "Checklist and Suggestions" and present feedback for their finalization. However, a consensus quickly emerged among the experienced and field-tested participants - including Chair Anstee and Mrs. Rehn - that it would be more productive for the Working Groups to instead try to formulate action-oriented recommendations that would be presented more as directives rather than as discretionary guidelines and would focus on the nine areas that had been identified as particularly critical for strengthening and implementing gender mainstreaming and gender balance in peace support operations. On this issue, Chair Anstee explained that she "would like to formulate specific recommendations, and would also like to engage entities outside the UN Secretariat", and referred to the Security Council and regional organizations. As regards the breakdown of the Working Groups, I recall that the titles were adjusted from those listed on the Programme, and I considered myself fortunate to be part of Working Group III on "Planning, Organization, Implementation and Monitoring of Gender Mainstreaming in Multidimensional Peace Support Operations" which had an operational 
focus and was chaired by Mrs. Rehn whom I knew. While the Working Group meetings were to officially start their work the next morning and continue throughout the day, the respective Chairpersons and Members engaged in informal discussions and brainstorming during dinner and the entire evening, including myself (especially with Mrs. Rehn).

When our Working Group met with Mrs. Rehn the next morning (30 May), we first discussed the most productive approach to take and agreed that, rather than the narrower task originally assigned by the organizers, it was important to focus our discussions on the entire cycle of a peacekeeping mission and the critical measures needed at each phase to foster gender mainstreaming and gender balance, as each had a "knock-on" effect with consequences for the next phase. On that basis, and taking account of the priority issues raised during the presentations and plenary discussions on the previous day as well as our informal brainstorming evening, the Working Group agreed that we should try to formulate and cluster our recommended actions under the following six broad headings that could be adjusted as we progressed: (1) Negotiations in furtherance of ceasefire and/or peace agreements, (2) Planning of UN peacekeeping operations and proposed operational plans, (3) Solicitation of personnel contribution and recruitment, (4) Training, (5) Implementation mechanisms, and (6) Monitoring, evaluation and accountability.

Our Working Group began tackling this task with steadfast determination to craft a document in the format of a directive that would clearly set out the required actions to be taken at each stage. From my experience in then having served in five UN peacekeeping operations (as a Legal Adviser in three) as well as in the UN Office of Legal Affairs (within the peacekeeping cluster) and DP KO, I firmly believed that this approach to our task would yield the best results but would not be easy, as it required that we take account of UN/D PKO guidelines and operational procedures that applied at each phase of the mission cycle in order to strategize on the critical "entry points" for gender mainstreaming. As my legal and peacekeeping functions during assignments in the field and at UN Headquarters extensively involved the review and application of such guidelines and procedures, I found it fulfilling to be able to use that experience in strategizing with Mrs. Rehn - a seasoned SRSG veteran - and the others to identify the optimum actions to implement gender mainstreaming at each mission phase. However, given that the Seminar presentations and discussions had raised a broad range of suggested requirements to strengthen gender mainstreaming (including gender balance) in peace support missions, a main challenge for the Working Group was to prioritize the actions that would likely be the most crucial and effective to ensure that gender mainstreaming would be systematically operationalized at every stage. With that strategy, 
and using the draft headings for our framework, we engaged in in-depth discussions and eventually decided to focus on UN/DPKO practices and procedures applicable at specific critical junctures throughout the mission cycle, including the following:

(a) the process for ceasefire and peace agreement negotiations, including for selection of the negotiating team;

(b) DPKO-led mission planning and the composition of an assessment team for a potential peace support operation;

(c) the Secretary-General's initial report to the Security Council proposing the mandate and operational concept for a new mission, and DPKO briefings to the Council, General Assembly, Member States and other relevant bodies;

(d) the formulation of Security Council resolutions establishing or extending peace support operations;

(e) the modalities, terms of reference, and eligibility criteria for solicitation of Member State military/police contributions and for civilian personnel recruitment for missions, including leadership positions;

(f) pre-deployment training standards and programmes for military, police and civilian personnel for missions, and induction and in-theatre briefings;

(g) the functions, roles and funding of mission gender units/advisers and related directives;

(h) the codes of conduct for mission personnel and the investigation mechanisms and procedures for allegations of sexual-based violations; and

(i) the format and mechanisms for reporting on missions as well as for the monitoring and evaluation of missions at field and Headquarters levels.

This turned out to be an intensive and rigorous process for our Working Group in terms of deciding both on the most impactful actions to recommend at each phase and on how best to formulate them in an effective and streamlined format. At the end of our Working Group's more than five hours of productive deliberations on our draft text that day, I was nonetheless concerned about the Seminar's approaching deadline for the reports of the three Working Groups to be presented the next morning. I therefore spoke with Mrs. Rehn who agreed that those interested could meet with her again after dinner in the conference room to further review our draft text. Just before dinner, there was also a meeting of the Chairpersons of the three Working Groups and the Rapporteurs. 
I vividly remember that a few members of our Working Group attended the resumed discussions after dinner in the small conference room but gradually left as the night progressed, and I remained alone with Mrs. Rehn and the LLU Rapporteur until the early hours of the next morning. We continued to brainstorm and refine the formulation of each of the actions recommended in the draft text, augmenting and revising as needed, until we were satisfied. While we were exhausted, I remember it as a very uplifting collaborative process because we were fueled by the prospect that the final combined product of the three Working Groups could make a real difference for women in the end.

\section{The plenary discussion of the Working Group reports led to a consensus on the Seminar's outcome documents and a strategic approach for their transmittal to UN Headquarters}

On 31 May, the Seminar's final morning began with an address entitled "The Way Ahead" by Ambassador Shaharyar Khan (former SRSG/United Nations Assistance Mission for Rwanda (UNAMIR) appointed in July 1994 during the Rwandan genocide) to set the stage for the presentation of the three Working Group reports and the subsequent plenary discussions. At the outset, Amb. Khan explained that, while serving in UNAMIR as a male SRSG dealing mostly with Rwandan women, he "felt handicapped without a gender unit or adviser" and that "perhaps the Mission would have been much more successful if he had had such a unit". After indicating that he would focus on "how far we have come on gender sensitivity, the grey areas, and the way ahead", he began by emphasizing, on a positive note, that "Namibia is a good example and has a provision in its Constitution which requires gender equality so that everyone is constitutionally bound to respect this principle". Amb. Khan further raised that "Namibia will soon become President of the UN Security Council in October 2000 so perhaps our reflections here can be reflected in the presidency of the Security Council", and also noted that Namibia's Minister for Women Affairs and Child Welfare, Hon. Netumbo Nandi-Ndaitwah, would be going to the UN General Assembly's Special Session on "Beijing +5 " in New York in June. He cited to some further progress made on the gender front, including that "there is now a principle of gender rights in peacekeeping" and that the past five years had shown that "women are more involved in peacekeeping and peacebuilding", and posited that "women are equated with peace" and not war. He then mentioned some of the grey areas "where the real opposition lies", particularly from elements "within the social fabric of certain countries which do not allow women to be part of a peacekeeping operation", while pointing out that this was "neither a moral nor rational position". On the way forward, 
Amb. Khan explained that there were "the three Es in the objectives to pave the road ahead", which he defined as Evolution, Education ("the electorate that sends those to New York") and Edict ("the demand to include gender sensitivity").

Amb. Khan's address was followed by a session entitled "Presentation of Working Group Reports and Discussion", and then, after a short tea break, a further two-hour session for plenary discussions. My recollection is that, driven by the high level of enthusiasm and determination that prevailed from the start, the three Working Group Chairpersons, Members, and Rapporteurs had already engaged quite extensively in informal discussions since the previous day, including over dinner, on each Group's recommendations for action as well as on a strategy for next steps. As a result, an informal consensus had emerged that the recommended actions of the respective Working Groups should be consolidated into the format of a single action plan clustered under appropriate headings, with an accompanying Declaration, and be forwarded to UN Headquarters. So, by the time we reached the session for the presentation of the reports of the three Working Groups and then engaged in plenary discussions, we had benefited from this informal consensus which enabled us to quickly make a formal decision that the Seminar would present its outcome in the form of a "Windhoek Declaration" and accompanying "Namibia Plan of Action on Mainstreaming a Gender Perspective in Multidimensional Peace Support Operations". The Working Group Chairpersons, Members and Rapporteurs therefore focused most of their efforts during the plenary session on combining and streamlining the texts of each Working Group's recommended actions into a consistent format for incorporation in the Plan of Action and grouping the actions under the relevant headings, as well as on reviewing and refining the Declaration text. I continued to work closely with Mrs. Rehn in providing suggested revisions to both documents, and we were pleased that our Working Group's text was basically incorporated in its entirety within the Plan of Action. As the participants shared a major concern that the Declaration must emphasize the need for high-level commitment by the key players to implement the Plan of Action and initiate the necessary follow-up measures, we ensured that the Declaration concluded with the following recommendation: "[T] he seminar recommends the Namibia Plan of Action and urges the Secretary-General to ensure that appropriate follow-up measures are taken to implement it, in consultation with Member States, and that periodic progress reviews are undertaken."

One outstanding issue that was raised during the plenary discussions led by Chairperson Anstee and Minister Nandi-Ndaitwah (which evolved into the Closing Ceremony) was how to most effectively transmit the Windhoek Declaration and accompanying Namibia Plan of Action to UN Headquarters 
in order to gain high visibility and buy-in for implementation, including who would be the most appropriate signatory and the addressee. Considering that Namibia hosted the Seminar and was a member of the Security Council (and would assume its presidency in October 200o), participants agreed that it would be most appropriate for the Government of Namibia to transmit the Windhoek Declaration and accompanying Plan of Action under a letter addressed to the UN Secretary-General. As regards the transmittal letter, I made the suggestion that it would seem important for the letter to specifically ask the Secretary-General to have the Declaration and Plan of Action distributed as an official document of both the UN Security Council and the General Assembly (then under the presidency of Namibia's Minister of Foreign Affairs) because the recommended actions would require follow-up and implementation by the broader UN system, the UN legislative bodies, and Member States. I mentioned that it would also ensure that the Declaration and Plan of Action would be forever recorded as an official UN document of both the Security Council and the General Assembly. The plenary endorsed my suggestion, and there was much enthusiasm among the participants. Everyone was especially excited because we believed that, given that Namibia's Minister of Foreign Affairs Theo-Ben Gurirab was then President of the UN General Assembly and would preside over its $23^{\text {rd }}$ Special Session (Beijing +5 ) in June 2000 and also that Namibia was serving on the Security Council and would assume its presidency in October, the Windhoek Declaration's urgent appeal for appropriate followup measures to be taken to implement the Plan of Action would be supported. We all felt overjoyed that our three days of intense discussions and strategizing had reached such a climax.

\section{B. The Impact of the Windhoek Seminar's Two Outcome "Blueprint" Documents on the Adoption of UN Security Council Resolution 1325}

In examining the impact of the Windhoek Declaration and the Namibia Platform for Action on the adoption, five months later, of UN Security Council resolution 1325 , it is crucial to initially take account that the Plan of Action presented a clear and concrete blueprint in listing 38 required actions under nine headings reflecting the areas that had emerged as particularly important for strengthening gender mainstreaming and gender balance in multidimensional peace support operations. Those headings included: (1) Negotiations in Furtherance of a Ceasefire and/or Peace Agreements, (2) Mandate, (3) Leadership, (4) Planning, Structure and Resources of Missions, (5) Recruitment, (6) Training, (7) Procedures, (8) Monitoring, Evaluation and Accountability, and (9) Public Awareness. Equally important, the Seminar participants ensured that the Windhoek Declaration presented a compelling 
visionary framework to substantiate the need for implementation of the Plan of Action. In this regard, the Declaration explained that, in a world riven by war, women and men "yearn for peace and are everywhere striving to resolve conflict and bring about peace, reconciliation and stability" in their communities and countries and through the UN and regional organizations. Yet, in noting that UN peace operations had evolved from peacekeeping "in its traditional sense" towards multidimensional peace support operations, the Declaration emphatically stated that "women have been denied their full role in these efforts, both nationally and internationally, nor has the gender dimension in peace processes been adequately addressed". ${ }^{24}$

Fueled by the pressing needs of women who had long been excluded from such participation in peace processes, from peace-making and peacekeeping to post-conflict reconstruction, the Declaration set out the following aims:

In order to ensure the effectiveness of peace support operations, the principles of gender equity and equality must permeate the entire mission, at all levels, thus ensuring the participation of women and men as equal partners and beneficiaries in all aspects of the peace process, from peacekeeping, reconciliation and peace-building, towards a situation of political stability in which women and men play an equal part in the political, economic and social development of their country. ${ }^{25}$

In explaining that the Seminar in Windhoek had considered these matters and looked at practical ways in which the UN system and Member States could bring the above-mentioned aims "closer to realization", the Declaration concluded with a strong appeal to the Secretary-General to ensure that appropriate follow-up measures would be taken to implement the Namibia Plan of Action. ${ }^{26}$ As elaborated below, that appeal had an enormous impact on the Security Council, as reflected by both the text of resolution 1325 and the many supportive statements made by Member States during the first Security Council open debate on "Women and Peace and Security".

\section{The Namibia Plan of Action's required measures are mirrored in the UN Security Council's calls for action in resolution 1325 (200o)}

The impact of the two historic "blueprint" documents produced by the Windhoek Seminar participants is clearly reflected in the text of Security

\footnotetext{
24 See UN Doc. A/55/138-S/200o/963, Annex I, $2^{\text {nd }}$ para.

25 Ibid., $3^{\text {rd }}$ para.

26 Ibid., $4^{\text {th }}$ para.
} 
Council resolution 1325 itself, starting with its strong preambular text in which the Council " $[r]$ cogniz [ed] the urgent need to mainstream a gender perspective into peacekeeping operations, and in this regard not[ed] the Windhoek Declaration and the Namibia Plan of Action on Mainstreaming a Gender Perspective in Multidimensional Peace Support Operations (S/200o/963)". ${ }^{27}$ Even more importantly, in the resolution's operative paragraphs, the Council called on Member States, the Secretary-General, all actors involved, and all parties to armed conflict to respectively take a number of actions that largely correspond with those among the 38 required measures listed in the Namibia Plan of Action. As just one of many examples, in the resolution, the Council " $[u] r g e s$ the Secretary-General to appoint more women as special representatives and envoys to pursue good offices on his behalf, and in this regard calls on Member States to provide candidates to the Secretary-General, for inclusion in a regularly updated centralized roster", and "[f]urther urges [him] to seek to expand the role and contribution of women in United Nations field-based operations, and especially among military observers, civilian police, human rights and humanitarian personnel". ${ }^{28}$ Such requested action had in fact been amplified and prioritized in the Namibia Plan of Action, which more expansively stipulated, among its eight listed "Leadership" and "Recruitment" requirements, the following:

- In accordance with the Secretary-General's target of 50 percent women in managerial and decision-making positions, more determined efforts must be made to select and appoint female Special Representatives of the Secretary-General and senior field staff for peace support operations.

- A comprehensive database with information specifically on female candidates with qualifications, both military and civilian, should be maintained.

- In DPKO an Advisory Board should be set up, preferably with qualified external participation, to ensure that this database and existing lists of female candidates are given due consideration.

- The United Nations must set an example by rapidly increasing the number of senior female civilian personnel in peace support operations in all relevant Headquarters departments, including DPKO, and in the field.

- Member States should be asked to increase the number of women in their military and civilian police forces who are qualified to serve 
in peace support operations at all levels, including the most senior. To this end, a stronger mechanism than the current note verbale to troop-contributing Nations should be developed. Requests to troopcontributing nations could be tailor-made to nations who are known to have suitable female staff, while other potential troop-contributing nations could be encouraged to develop longer-term strategies to increase the number and rank of female personnel in their respective forces.

- The terms of reference, including eligibility requirements, for all heads of mission components and their personnel should be reviewed and modified to facilitate the increased participation of women, and, depending on the outcome of that review, special measures should be taken to secure this goal. ${ }^{29}$

As another example, the Council's resolution "urges the Secretary-General to ensure that, where appropriate, field operations include a gender component",30 which echoes the Plan of Action's even more robust call that "[a] gender affairs unit is crucial for effective gender mainstreaming and should be a standard component of all missions" and "should be adequately funded and staffed at appropriate levels and should have direct access to senior decision-makers". ${ }^{31}$

It is also significant that the Security Council, in the resolution's penultimate operative paragraph, underscored the need for timely implementation of gender mainstreaming and progress oversight as it " $r$ ]equests the SecretaryGeneral, where appropriate, to include in his reporting to the Security Council progress on gender mainstreaming throughout peacekeeping missions and all other aspects relating to women and girls". ${ }^{22}$ The Council's request aligns with the Plan of Action's strong emphasis on "Monitoring, Evaluation and Accountability", which includes the following among the seven required measures:

- Accountability for all issues relating to gender mainstreaming at the field level should be at the highest level, vested in the SecretaryGeneral's Special Representative, who should be assigned the responsibility of ensuring that gender mainstreaming is implemented in all areas and components of the mission.

- Monitoring and evaluation mechanisms to assess the implementation of the United Nations gender mainstreaming objectives should be

\footnotetext{
29 See UN Doc. A/55/138-S/200o/963, Annex II, paras. 3 and 5 .

30 See UN Doc. S/RES/1325 (2000), para. 5 .

31 See UN Doc. A/55/138-S/200o/963, Annex II, para. 4.

32 See UN Doc. S/RES/1325 (2000), para. 17.
} 
established at United Nations Headquarters and at peacekeeping missions, in consultation with the Division for the Advancement of Women.

- The current format of reporting, particularly with regard to situation reports and periodic reports of the Secretary-General, should include progress on gender mainstreaming throughout peacekeeping missions.

- There should be periodic and end-of-mission evaluations, led by an independent external team, of the degree to which the United Nations gender mainstreaming approach and objectives have been integrated into all policies and activities of each peace support operation. The first studies should be on East Timor and Kosovo. ${ }^{33}$

In addition, the Council's invitation to the Secretary-General "to carry out a study on the impact of armed conflict on women and girls, the role of women in peace-building and the gender dimensions of peace processes and conflict resolution" and "to submit a report to the Security Council on the results of this study and to make this available to all Member States of the United Nations"34 is in line with the Namibia Plan of Action's call that "[r]esearch should be encouraged on the short- and long-term effects of the gender dimension of peace support operations on the host country population" and "should be designed to strengthen host country research capacity, in particular that of women researchers". ${ }^{35}$

\section{(2) Member States embraced the Windhoek Declaration and Namibia Plan of Action during the first UN Security Council open debate on "Women and Peace and Security"}

The impact of the Windhoek Seminar's two historic outcome documents is also strikingly visible in the statements made by Member States during the UN Security Council's first thematic open debate on "Women and peace and security" held on 24 and 25 October 2000 under Namibia's presidency ${ }^{36}$ that, together with the Arria-formula meeting held on 23 October, preceded the adoption of landmark resolution 1325 on 31 October. In their statements, 8 of the 15 Security Council members and 12 of the 26 non-Council members explicitly expressed support for the Windhoek Declaration and the Namibia

33 See UN Doc. A/55/138-S/2000/963, Annex II, para. 8.

34 See UN Doc. S/RES/1325 (2000), para. 16.

35 See UN Doc. A/55/138-S/2000/963, Annex II, para. 8.

36 See UN Doc. S/PV.4208; UN Doc. S/PV.4208 (Resumption 1); and UN Doc. S/PV.4208 (Resumption 2). 
Plan of Action, ${ }^{37}$ with some citing to and commending particular recommended actions presented in them. In addition, many other Member States conveyed support for various proposed measures included in the Plan of Action without specifically referring to it.

As just a few examples, Jamaica (represented by the only female Permanent Representative on the Security Council) highlighted that the Windhoek Declaration represented a valuable step forward and passionately appealed to the Council to move from rhetoric to action in stating:

These efforts [undertaken by women in Somalia, Burundi, East Timor, Guatemala, Sierra Leone and many other countries], which have recently engaged the attention of the Council, point unequivocally to the strategic importance of women in relation to peace. However, despite the role of women in promoting peace and the progress made in implementing various international agreements, much remains to be done to ensure that women are increasingly seen as equal partners. The Windhoek Declaration, adopted in Namibia in May 2000, represents a valuable step in highlighting the importance of this issue and of mainstreaming a gender perspective into peace support operations.

In recent assessments of United Nations peace operations, a number of important elements which are relevant to the incorporation of a gender dimension in peacekeeping have unfortunately been overlooked. It is also a matter of concern for my delegation that women are still underrepresented in decision-making in the area of conflict resolution. It is in this context that, while we recognize the important recommendations contained in the Brahimi report, we call for the implementation of these recommendations, including, where appropriate, the participation of women at all levels....

Today, as we celebrate United Nations Day, it is fitting that we draw attention to the role of women as agents for the promotion of peace, security

37 The eight Security Council members included, in the order of their statements at the open debate, the following: Jamaica (S/PV.4208, p. 11), Argentina (ibid., p. 16), Bangladesh (ibid., p. 21), Russian Federation (ibid., p. 21), Canada (ibid., p. 25), Malaysia (ibid., pp. 2728), Mali (ibid., p. 31), and Namibia (S/PV.4208 (Resumption 2), pp. 13-14). The twelve non-Council members included, in the order of their statements at the resumed open debate sessions, the following: Mozambique (S/PV.4208 (Resumption 1), p. 2), Democratic Republic of the Congo (ibid., p. 6), Liechtenstein (ibid., p. 11), Japan (ibid., p. 15), India (ibid., p. 20), Zimbabwe (ibid., p. 23), Tanzania (ibid., p. 25), Australia (ibid., p. 27), Croatia (ibid., p. 29), Norway (S/PV.4208 (Resumption 2), p. 7), Rwanda (ibid., p. 9) and Botswana (ibid., p. 10). 
and development. The time has come for us to move from rhetoric to action. The women of the world expect no less from the Security Council. ${ }^{38}$

Mali (a Council member), in highlighting that the country's women had historically played an important role in the prevention, settlement and management of conflict, including during the crisis in northern Mali when they participated in negotiating the National Peace Pact, conveyed its firm support for the Namibia Plan of Action as follows:

The women of Mali remain convinced that in order to ensure the effectiveness of peacekeeping operations - which today have progressed from traditional peacekeeping operations to multidimensional activities in support of peace - the principles of gender equity and equality must find a place in all missions, at all levels, in order to guarantee men and women the same role in every element of the peace process: peacekeeping, reconciliation and peace-building. In this connection, we firmly support the Namibia Plan of Action on Mainstreaming a Gender Perspective in Multidimensional Peace Support Operations, which was adopted at Windhoek on 31 May 2000. ${ }^{39}$

Mali further asserted that, in order to promote a peaceful world for all in the new millennium, it was imperative for the Council to take action to ensure that women are included in all aspects of peace processes:

At a time when mankind must more than ever before be the measure of the new millennium, and when people expect the United Nations to be the promoter and guarantor of a world of progress for all - a world of peace, solidarity and sharing - the Security Council must demonstrate a clear and discernible capacity for action that both deters and reassures. To achieve that capacity we must fully integrate women as never before as partners and beneficiaries in all aspects of a peace process: peacekeeping, reconciliation and peace-building. ${ }^{40}$

Australia, in emphasizing that the Windhoek Declaration and the Namibia Plan of Action constituted a very important step, expressed its support for their key conclusions and recommendations as well as its hope that the Council resolution to be adopted would be strong and action-oriented:

$38 \quad$ UN Doc. S/PV.4208, pp. 11-12.

$39 \quad$ Ibid., p. 31.

$40 \quad$ Ibid. 
...[T]he Council itself gave a valuable boost to this in March this year, in the statement it issued on International Women's Day, when it recognized publicly the link between peace and equality between men and women. Today's debate builds on this acknowledgement - that equal access and full participation of women in power structures and their full involvement in all efforts for the prevention and resolution of conflicts are essential for the maintenance and promotion of peace and security. The Windhoek Declaration of May 2000 and the Namibia Plan of Action on 'Mainstreaming a Gender Perspective in Multidimensional Peace Support Operations', which were informed by the laborious threeyear study...were another very important step. Australia certainly can support many of their key conclusions and recommendations: that the gender dimensions of peace processes have not been adequately recognized; that women have so far been denied their full role in national and international peacekeeping and peacemaking operations; that the mandates of United Nations preventive peace missions, peacekeeping operations and peace-building should include provisions for women's protection and address gender issues; and that peace support operations should include appropriately staffed and integrated gender units and gender advisers.

...I have not seen a draft of the resolution that the Council may be planning to adopt, but I hope it will be strong and, above all, that it will be action-oriented and will pick up the practical suggestions that have been put forward today by a number of delegations...The resolution should help us all not just to talk the talk, but to walk the walk of women's involvement. ${ }^{41}$

A few Member States (e.g., Australia, Canada, Jamaica) ${ }^{42}$ also welcomed DPKO's Report on "Mainstreaming a Gender Perspective in Multidimensional Peace Operations" (issued in July 2000 in preliminary form), ${ }^{43}$ which

41 UN Doc. S/PV.4208 (Resumption 1), pp. 27-28. See also the statement issued by the President of the UN Security Council to the press of 8 March 2000 on the occasion of International Women's Day (UN Press Release SC/6816).

42 See UN Doc. S/PV.4208, pp. 12, 25; and UN Doc. S/PV.4208 (Resumption 1), p. 27.

43 See Report on Mainstreaming a Gender Perspective in Multidimensional Peace Operations (United Nations, Lessons Learned Unit, Department of Peacekeeping Operations, July 2000). The Introduction to the Report explained its preliminary status: "It should be noted that this is a preliminary report, which was prepared in less than five months so that it would be available for the Beijing-plus-five review held in June 2000 at a special session of the General Assembly. It has relied heavily on interviews and the analysis of documents. 
incorporated many of the recommendations of the Windhoek Declaration and the Namibia Plan of Action and was based on a three-year Study undertaken by the Lessons Learned Unit (LLU) in cooperation with the UN Division for the Advancement of Women/Department of Economic and Social Affairs.

It is also noteworthy that various Member States, in voicing their support for the Windhoek Declaration and the Namibia Plan of Action, conveyed that the recommended actions therein should be taken into account in the implementation of the "Report of the Panel on United Nations Peace Operations" chaired by Mr. Lakhdar Brahimi and issued on 21 August 200o, ${ }^{44}$ which lacked any section on gender. For example, Bangladesh (a Council member), in expressing that "[w]e support the Windhoek Declaration and the Namibia Plan of [Action]", further stated that "[w]e believe that the actions identified in the Declaration can complement and fill in the blanks in the recommendations of the Brahimi Panel's report" and that "a gender dimension of peacekeeping and peace support operations must be highlighted; it is a missing link as far as the report is concerned". ${ }^{45}$ The Democratic Republic of the Congo, in emphasizing that "a great deal remains to be done to recognize fully the role of women in peacekeeping and peace-building", stated that it "supports the Windhoek Declaration and the Namibia Plan of Action, adopted last May, because they are valuable documents that should be applied, particularly in the implementation of the Brahimi report, in order to enhance effectiveness". It emphatically added:

It is absolutely essential that initiatives aimed at resolving conflicts and consolidating peace take into consideration women's concerns, experience and perspective. My delegation dares to hope that the organs of the United Nations will be able to incorporate these concerns and work to promote increased awareness of the capacities of women, in particular those affected by armed conflicts, as well as their ability to contribute to the promotion of a gender perspective in all peace-building activities. Women must be involved in the conflict-prevention and conflictresolution mechanisms so that they can give humankind the benefit of

It has not been possible to collect extensive empirical data, and the data on a most important subject - the effect of a peacekeeping mission on local women - is, at best, rudimentary. Some findings are presented; they are drawn principally from the case studies. A more exhaustive and systematic study is needed, and will be pursued as resources become available. It is also important that current peace operations, such as those in East Timor and Kosovo, and future peace operations that have gender components be evaluated to determine what has and has not been effective." (para. 5)

UN Doc. S/PV.4208, p. 21. 
their ability to build consensus, resolve conflicts and build peace. There can be neither equality nor development without peace and justice. ${ }^{46}$

In addition, Liechtenstein welcomed the Windhoek Declaration and the Plan of Action's proposal that "an advisory board should be set up within the Department of Peacekeeping Operations to ensure that a comprehensive database as well as existing lists of female candidates be given due consideration", and pointed out that "gender issues need to be mainstreamed into the actions that will result from this debate and, in particular, also in the implementation of the recommendations contained in the Brahimi report, which lacks a chapter on gender". In also asserting that "[e]very attempt towards democratization and peace-building must be based on fundamental values, including the principles of gender equality," and that "[w]omen must therefore be participants in all peace processes and at any stage of these processes", the Permanent Representative noted that "[t]oday's debate is a concrete step towards realizing this goal". 47

Presiding as Council President, Namibia highlighted and elaborated on a number of specific recommendations in the Plan of Action, and stated that it "fully endorses the Plan of Action and urges all concerned to take its proposals into account when formulating policy objectives and implementation plans in respect of the Brahimi report". The Permanent Representative further stated that "[1]ike other countries represented here, Namibia laments the Brahimi report's lack of clear and categorical emphasis on gender perspectives and on an effective role for women in conflict resolution, peacekeeping and peacebuilding" which "should be rectified during the implementation process" ${ }^{48}$ Underscoring that the open debate set a historic precedent, he implored the Council to seize on this "new beginning" by fully utilizing the contributions that women can make in all efforts to maintain international peace and security:

This open debate is the first of its kind convened by the Council. It is a good omen that it is taking place on United Nations Day in the year 2000. Fifty-five years ago today the Charter of the United Nations came into being. Yet it has taken the international community many decades to recognize that women are among the principal victims of war, conflict and insecurity. They must thus be treated as indispensable partners in the maintenance of international peace and security. Today's meeting therefore constitutes a new and significant beginning for the Security

\footnotetext{
$46 \quad$ UN Doc. S/PV.4208 (Resumption 1), p. 6.

47 Ibid., p. 11.

48 See UN Doc. S/PV.4208 (Resumption 2), pp. 13-14.
} 
Council; the Council should conscientiously make use of the contributions women can make in dealing with the issues of preventive diplomacy, conflict prevention, protection of women and girls in armed conflict and peace-making, peacekeeping and support operations. ${ }^{49}$

In concluding, he pointed out that " $\mathrm{t}] \mathrm{he}$ views expressed today indicate that the maintenance of peace and security is a collective effort" which "should therefore involve all women and men for our common good", and urged: "To that end, let us put our words into deeds to make this, our one world, a peaceful and secure place for this and future generations." ${ }^{\prime 50}$

With the focus on implementation, various Member States specifically embraced the Windhoek Declaration's urgent call for the Secretary-General to ensure follow-up action to implement the Namibia Plan of Action. As just a few examples, India, in emphasizing the "need to take practical and effective steps to mitigate the impact of conflict on women and to enhance their ability to restore and preserve peace", stated that "[t]he Namibia Plan of Action on Mainstreaming a Gender Perspective in Multidimensional Peace Support Operations has many useful elements" and that "[w]e support the call in the Windhoek Declaration of 31 May 2000 urging the Secretary-General to ensure that appropriate follow-up measures are taken to implement this Plan of Action, in consultation with Member States". ${ }^{11}$ Similarly, Tanzania expressed that it "supports the Namibia Plan of Action and the call made to the SecretaryGeneral to ensure that appropriate follow-up measures are undertaken to implement it", and further called on the international community and Governments "to intensify efforts aimed at the realization of the objective [for women to play an equal part in security and maintaining peace], including the enhancement of the role of women in various phases of the transition to peace and post-conflict reconstruction". 52

In lauding the Namibia Plan of Action and its remedial measures, Malaysia (a Council member) emphasized that increased and sustained follow-up action was needed to integrate women and gender dimensions in all stages of peacekeeping operations and peace processes generally:

...Women are hardly ever considered to be an integral and essential element in political decisions, conflict resolution, peace-building and peace

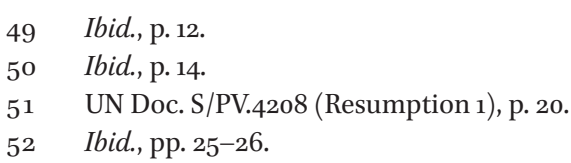


processes. Despite the important perspectives women have with regard to conflict situations, peacemaking and peacekeeping, they are underrepresented in decision-making positions at all levels....

Although the problems have been recognized, more needs to be done in terms of follow-up actions. Several remedial actions have been identified in a number of important initiatives on women, such as the Namibia Plan of Action, as well as the 1996 Machel Report and the 2000 Machel Review....Thanks to the Namibia Plan of Action, among others, a study assessing the extent to which a gender perspective is included in all stages of peacekeeping operations is now being undertaken within the Department of Peacekeeping Operations. Clearly, important steps have been taken in giving substance to the role of women in peace and security. All of these measures must be followed-up and sustained. Today's meeting of the Council and the resolution that will be adopted contribute substantively to these efforts... ${ }^{53}$

Further, Zimbabwe referred to the Windhoek Declaration's sobering observations regarding the "untenable condition" of women, and underscored the continuing need for follow-up action to address it in urging that:

...Rather than being treated as an agenda item to be ticked off the Council's work programme at the end of this meeting, this issue [of women and peace and security] must be pursued on a continuing basis, and can be ignored only at our peril....

Today's specific reference to 'women and peace and security' reflects our acknowledgement of the particular vulnerabilities of women in conflict situations. It also reflects our acknowledgement of current inequalities in decision-making and power structures and, happily, our sincere endeavour to address that untenable condition.

That women have everything to lose and an unbearable cost to pay in the wake of armed conflict establishes an undisputed mandate and role for them in all matters of peace and security. Unfortunately, and as correctly observed in the Windhoek Declaration of 31 May 2000 on the tenth anniversary of the United Nations Transition Assistance Group: 'So far, women have been denied their full role in these efforts, both nationally 
and internationally, nor has the gender dimension in peace processes been adequately addressed. 54

From my decades of UN work, I feel confident to say that the undeniable impact that the Windhoek Declaration and the Namibia Plan of Action had on the Security Council, as reflected above, is no small feat, especially when compared to end products of other UN seminars. It is all the more striking given that the thematic topic of women, peace and security had long been considered by some Council Members - including among the permanent five - as too "soft" for inclusion in the Council's agenda.

\section{Closing Reflections on an Extraordinary and Uplifting Windhoek Seminar That Ignited a Revolutionary Outcome but Has Yet to Trigger Revolutionary Change}

When preparing for my travel from Kosovo to Windhoek for that Seminar in May 2000, I had become quite stressed as I was performing my demanding functions as the UNMIK Chief of Staff while also pouring my heart and latenight efforts into drafting my presentation for the Seminar. I considered myself privileged to be asked to speak at such an unprecedented forum aimed at addressing how to strengthen gender mainstreaming in multidimensional peace support operations which was of critical importance and long overdue, as I could attest from having then served in five UN peacekeeping operations over 17 years. But I felt tremendous pressure as I wanted to ensure that my presentation would give due justice to a major problem facing the women of Kosovo their exclusion from most leadership and governance positions that could give them an opportunity to be fully involved in the rebuilding of their war-stricken lives and communities - as well as the Mission's strenuous efforts led by SRSG Kouchner to improve their representation. In focusing on the tenacious efforts being made by the SRSG and the entire Mission leadership and staff to prioritize the need to increase the representation of women in the new central and municipal structures of the interim shared administration for Kosovo, I spent endless hours compiling and double-checking figures to accurately reflect the progress that had been made in the appointment of women in each of those structures as well as some of the gaps and constraints that had arisen.

I soon realized, though, that those exhausting efforts proved to be not only thoroughly worthwhile but also a small part of a much more important collective endeavor that would considerably influence the course of "how 
future business would be done" in planning and carrying out UN peace support operations. As I sat on that return flight to Kosovo after having been immersed in such an energy-fueled, three-day marathon Seminar to make it to the finish line, I felt so proud that those 62 participants (including 11 men) - emboldened by a few courageous and pioneering female leaders and the inspiring words of our Namibian hosts - had managed to collectively score such a victory for women. In the compelling setting of Namibia, we had produced, through creative brainstorming and adopting an action-driven approach over bureaucratic instructions, two ground-breaking documents that we hoped would have enormous future impact and ensure that the milestone achieved in UNTAG would not be rolled back: the Windhoek Declaration and the accompanying Plan of Action on Mainstreaming a Gender Perspective in Multidimensional Peace Support Operations. Equally important, we had plotted a strategy on how the transmission of those two documents under a letter to the Secretary-General at UN Headquarters would ensure that they landed in the laps of all Security Council members and the entire General Assembly membership so that pressure would be on them to heed our call to take follow-up measures to implement them.

The momentum did indeed build over the following five months in the UN Security Council, much to the credit of Namibia along with a few other Council members, such as Bangladesh, Canada, Jamaica (with the only female Permanent Representative) and Mali, as well as many committed civil society organizations and other stakeholders worldwide, and ultimately culminated in the adoption of landmark Security Council resolution 1325 on 31 October 2000. As elaborated earlier, the text of that historic resolution - the first ever to consider the importance of the role of women in peace and security processeswas undeniably influenced by the vision and blueprint for concrete action so clearly laid out in the Windhoek Declaration and the Namibia Plan of Action. And I would posit that the depth of that influence was immeasurable, especially when considering the statements made during the Security Council's open debate on 24-25 October 2000 prior to that resolution which generated so much hope that the measures set out in the Namibia Plan of Action would be energetically implemented. The hope stirred by the many supportive and sometimes impassioned statements is not easy to describe, including when the Deputy Permanent Representative of China uncharacteristically stated: "We would be encouraged to see, some day in the future, in a war-torn area, a peacekeeping operation composed entirely of women."55

While an analysis of the progress made since that watershed Seminar twenty years ago in implementing gender mainstreaming throughout all stages of UN

See UN Doc. S/PV.4208, p. 17 . 
peace support operations is a complex project for another time, I will say that, unfortunately, there is still a very long way to go as gender mainstreaming is neither systematic nor sufficient. That stark reality has not only been deeply disappointing but anguishing for so many, particularly the countless number of marginalized and vulnerable women in conflict-affected countries across the globe who had hoped that their shattered lives would be uplifted by what the Windhoek Declaration, Namibia Plan of Action and Security Council resolution 1325 had envisaged for them two decades ago.

Those broken hopes, however, were re-ignited by the bold Global Study on the Implementation of United Nations Security Council Resolution 1325 issued in October $2015,{ }^{56}$ which was authored by independent expert Radhika Coomaraswamy (former Special Representative of the Secretary-General for Children and Armed Conflict) at the request of the Secretary-General. The Security Council, in its resolution 2122 of 18 October 2013, had invited the Secretary-General "to commission a global study on the implementation of resolution 1325 (2000), highlighting good practice examples, implementation gaps and challenges, as well as emerging trends and priorities for action" in preparation for the High-Level Review to be convened by the Council in 2015 to mark the $15^{\text {th }}$ anniversary of resolution 1325 , and to also submit the results of this study within his 2015 annual report to the Council and make it available to all Member States. ${ }^{57}$ The 416-page Global Study publication (launched in conjunction with the Security Council's High-Level Review) presented not only a comprehensive and sobering assessment of the many persisting gaps and challenges, but also a clear forward-looking blueprint to advance the agenda

56 See Preventing Conflict, Transforming Justice, Securing the Peace: A Global Study on the Implementation of United Nations Security Council Resolution 1325 (UN Women, New York, 2015, ISBN: 978-o-692-54940-7), available at http://wps.unwomen.org/.

57 See UN Security Council resolution 2122 of 18 October 2013 (UN Doc. S/RES/2122 (2013)), para. 16. In resolution 2122, the Security Council " $[$ r]eiterate $[d]$ its intention to convene a High-level Review in 2015 to assess progress at the global, regional and national levels in implementing resolution 1325 (2000), renew commitments, and address obstacles and constraints that have emerged in the implementation of resolution 1325 ", and, in preparation for the High-Level Review, invited the Secretary-General "to commission a global study on the implementation of resolution 1325 (2000)" (paras. 15-16). In 2014, the Secretary-General requested Ms. Radhika Coomaraswamy to be the lead author of the global study, who was supported by a 17-member High-Level Advisory Group constituted from all regions of the world (which included Mrs. Rehn), and UN Women served as the secretariat of the study. The UN Inter-Agency Standing Committee on Women, Peace and Security (comprising representatives of $21 \mathrm{UN}$ entities) also provided comments to the lead author throughout the preparation of the study; the author of this article was a DPKO representative on the Committee. As a result of over a year-long process, the Global Study was issued (see Preventing Conflict, Transforming Justice, Securing the Peace: A Global Study on the Implementation of United Nations Security Council Resolution 1325). 
by detailing robust recommendations for action needed by Member States, the UN, regional and international organizations, civil society, donors, media outlets and other relevant actors - including the UN Security Council itself for full implementation of the commitments set out in landmark resolution 1325. The powerful Study presented some 196 recommendations under eleven thematic areas, and, for each recommendation, clearly specified which of the above-mentioned actors needed to take required actions for full implementation. In the Foreword, then UN Secretary-General Ban Ki-moon stressed that "[e]mpowering women to end and prevent conflicts is essential and urgent", and, in commending the Study, unequivocally stated that: "It is a call to action that all should heed." 58

In his report to the Security Council on "Women and peace and security" of 16 September 2015, the Secretary-General shared select findings and recommendations from the Global Study, which he explained "were informed by a series of regional consultations and country visits, direct inputs from all actors, cutting-edge research and data analysis, including updated data for indicators to track the implementation of resolution $1325 \ldots . . .{ }^{59} \mathrm{He}$ also expressed that he was "particularly pleased by the efforts made to ensure synergies with related reviews, including the High-level Independent Panel on Peace Operations, the Advisory Group of Experts on the 2015 Review of the United Nations Peacebuilding Architecture, the preparations for the 2016 World Humanitarian Summit, the 2030 Agenda for Sustainable Development and the 20-year review and appraisal of the implementation of the Beijing Declaration and Platform for Action". Once again, the Secretary-General made a firm appeal for action in stating: "I strongly encourage all stakeholders to seriously consider the concerns voiced in the study and to respond to the demands for stronger action and specific results." ${ }^{\prime 6}$

In addition to that Secretary-General's report and the Global Study, further hope for accelerated progress was raised by the broad-ranging action taken by the Security Council at its ministerial-level open debate on "Women and peace and security" held on 13-14 October 2015 (the "High-Level Review") under Spain's presidency ${ }^{61}$ to mark the $15^{\text {th }}$ anniversary of resolution 1325 . Following

$5^{8}$ See Foreword to the Global Study (Preventing Conflict, Transforming Justice, Securing the Peace: A Global Study on the Implementation of United Nations Security Council Resolution 1325), p. 4.

59 See UN Doc. S/2015/716 of 16 September 2015, para. 3 .

6o Ibid.

61 The Permanent Representative of Spain to the UN addressed a letter to the SecretaryGeneral of 1 October 2015 forwarding a concept note for the Security Council open debate and asking for its circulation as a document of the Council (see UN Doc. S/2015/749 of 1 October 2015 and the Annex). During the open debate on 13-14 October 2015, statements 
opening remarks by the Secretary-General calling for intensified action ${ }^{62}$ as well as briefings by the Executive Director of UN Women ${ }^{63}$ and three civil society representatives, the Security Council unanimously adopted resolution 2242 on 13 October $2015^{64}$ in which it " $[w] e l c o m[e d]$ the report of the SecretaryGeneral of 16 September 2015 (S/2015/716) submitting the results of the Global Study on the implementation of resolution 1325 " and also "recogniz [ed] with appreciation all the work undertaken for the Global Study and encourag[ed] close examination of its recommendations". ${ }^{65}$ In that resolution, the Council further emphasized that "persisting barriers to the full implementation of resolution 1325 (2000) will only be dismantled through dedicated commitment to women's participation and human rights, and through concerted leadership, consistent information and action, and support, to build women's engagement in all levels of decision-making". ${ }^{66}$ In recognizing "the opportunity

were made by 98 Member States, one Non-Member State Permanent Observer, and six regional organizations (see UN Doc. S/PV.7533 and UN Doc. S/PV.7533 (Resumption 1)).

62 See UN Doc. S/PV.7533, pp. 3-4. In his remarks to the Security Council, the SecretaryGeneral emphasized that " $\mathrm{t}$ ] he global study on the implementation of resolution 1325 (2000) is an important part of the United Nations agenda for change", and concluded by urging: "Let us heed the call for action and work together to empower women and girls, protect their human rights and advance world peace for everyone - all cornerstones of the 2030 Agenda for Sustainable Development and a life of security and dignity for all." (p. 4)

63 See ibid., pp. 4-6. The Executive Director of UN Women, in concluding her briefing to the Security Council, appealed for action to implement the Global Study's targeted recommendations: “...Our challenge now will be taking steps toward proper funding and execution of the study's ambitious targets. Many of the much-needed changes are in the hands of the Member States represented in this Chamber. As I close, let me remind the Council of the inescapable logic of the study's findings, reflected in the SecretaryGeneral's report, and which should galvanize us to action. These are some key areas. Every peace process we wish to be sustainable must include women. We must incentivize countries to transform the security forces in all United Nations Member States, increasing the numbers of women in leadership positions; we must also learn to value the voice of civilians in peacemaking. We must take strong action against violators, working as a group to ensure that individual countries are not able to shield perpetrators of crimes from justice. We must take steps to build the status of women's human rights defenders, and we must act and invest to prevent conflict. Where conflict is entrenched, we must move away from a view of peacekeeping as a series of short-term projects and treat peacebuilding as a long-term action, with long-term funding, and women as core partners. Preventing conflict and peacebuilding is an institution we need to build and invest in, as we do for the health or education institutions that we cannot do without." (p. 6)

64 See UN Doc. S/RES/2242 (2015) of 13 October 2015. Security Council resolution 2242, the eighth resolution on the topic of women and peace and security, was adopted ahead of the Council's open debate on 13-14 October 2015.

66 Ibid., $11^{\text {th }}$ preambular para. 
and need for far greater implementation of the women, peace and security agenda", the Council stated that it

...remain [ed] deeply concerned by the frequent under-representation of women in many formal processes and bodies related to the maintenance of international peace and security, the relatively low number of women in senior positions in political, peace and security-related national, regional and international institutions, the lack of adequate gendersensitive humanitarian responses and support for women's leadership roles in these settings, insufficient financing for women, peace and security, and the resulting detrimental impact on the maintenance of international peace and security. ${ }^{67}$

Driven by these concerns, the Council presented, in its seven-page resolution 2242, sweeping calls for action by Member States (including police- and troopcontributing countries), the Secretary-General, relevant UN entities, intergovernmental, regional and sub-regional organizations, and other relevant actors to improve implementation of its landmark women, peace and security agenda. Among its many calls for action, the Council resolution:

(a) called for Member States to ensure increased representation of women at all decision-making levels in national, regional and international institutions and mechanisms for the prevention and resolution of conflict, and encouraged those supporting peace processes to facilitate women's meaningful inclusion in negotiating parties' delegations to peace talks;

(b) called upon Member States to further integrate the women, peace and security agenda into their strategic plans such as national action plans and other planning frameworks, with sufficient resources, through broad consultations, including with civil society, in particular women's organizations;

(c) urged the Secretary-General and relevant UN entities, including but not limited to D PKO, the Department for Political Affairs (DPA), and the Peacebuilding Support Office (PBSO), to redouble their efforts to integrate women's needs and gender perspectives into their work, including in all policy and planning processes and assessment missions, and in relation to requests made in resolution 2122 (2013), and to address deficits in accountability; 
(d) urged DPKO and DPA to ensure the necessary gender analysis and technical gender expertise is included throughout all stages of mission planning, mandate development, implementation, review and mission drawdown, ensuring the needs and participation of women are integrated in all sequenced stages of mission mandates, and called for senior gender advisors and other gender officer posts to be budgeted for and speedily recruited where appointed in special political missions and multidimensional peacekeeping operations;

(e) called upon the Secretary-General to initiate, in collaboration with Member States, a revised strategy to double the numbers of women in military and police contingents of UN peacekeeping operations over the next five years;

(f) urged police- and troop-contributing countries to provide robust pre-deployment training on sexual exploitation and abuse and vetting of their peacekeeping personnel, to conduct swift and thorough investigations of their uniformed personnel and, if appropriate, to prosecute, and to inform the United Nations in a timely manner of the status and outcome of investigations; and

(g) urged Member States to strengthen access to justice for women in conflict and post-conflict situations, including through the prompt investigation, prosecution and punishment of perpetrators of sexual and gender-based violence, as well as reparation for victims as appropriate. 68

And yet, since that profound Global Study with its blueprint of actionable recommendations and the Security Council's sweeping calls for action in its resolution 2242, the extent and pace of progress over the past five years has continued to be painfully slow in many critical areas. While this lagging progress in implementation is deeply troubling and must be countered with deliberate and comprehensive scaled-up action, the experience of that unprecedented Windhoek Seminar in May 2000 and its consequential and "revolutionary" effects will never be forgotten, and neither will the two fearless and bold women leaders and SRSG veterans - Dame Anstee and Mrs. Rehn who were so instrumental in steering the way. And I personally owe them a huge debt of gratitude for infusing me in Windhoek with an even stronger determination and enthusiasm to continue on my peacekeeping and gender justice path and further contribute to UN efforts to help make a difference in the lives of the many vulnerable but courageous women and girls in conflict

Ibid., paras. 1, 2, 4, 7, 8, 9 and 14 . 
zones across the globe. So too do I owe so much to those two empowering male SRSGs in Namibia and Kosovo (my "bosses"), Mr. Ahtisaari and Mr. Kouchner, who demonstrated that actively promoting the advancement of women - both within UN ranks and the host country - as well as their full inclusion in all phases of peace processes cannot be regarded as a task for women leaders only but, rather, as an equal responsibility for the many more men who end up in positions of influence and can serve as inspiring role models for so many, girls and boys and women and men alike.

At this juncture, I still maintain hope that the shamefully sluggish record of 1325-related implementation action, including on the 2015 Global Study's broad-ranging recommendations, can be reversed and, further, that the 2oth anniversary of resolution 1325 can be catapulted as a trigger for serious progress and much-needed change throughout this decade. Translated into "operational plain-speak", I believe that, in order for this trigger to be activated and work, we need, at a minimum, the following:

(a) strong and principled leadership of the UN Secretary-General to spearhead and assume accountability for an initiative to accelerate implementation of the outstanding recommendations of the Global Study and of the ten Security Council resolutions on "Women, peace and security", and the appointment of a respected Imminent Expert (reporting directly to him) to help direct and oversee the process, which would involve liaison with relevant UN entities, Member States and other actors;

(b) the issuance by the Secretary-General of a targeted, time-bound and sufficiently-resourced plan for implementation of these outstanding recommendations and accompanying arrangements for an independent and transparent accountability mechanism for progress tracking, monitoring and reporting (accessible to the public), both of which would be formulated under the lead of the Imminent Expert in consultation with a high-level expert advisory group of diverse representation as well as with relevant UN entities, Member States and other actors; and

(c) clear arrangements for strengthened coordination and prioritization of efforts to be undertaken respectively by all of the relevant actors (at national, regional and international levels), which would be set out within the framework of the implementation plan.

With bold UN leadership steering such a time-bound initiative with "accountability safeguards", as well as unrelenting pressure by all those who believe in the need for gender equality and for women to be fully involved as 
equal partners in all aspects of peace and security processes, we can - and must - drastically accelerate this struggle to achieve the much-awaited results envisaged by those enthusiastic Seminar drafters of the Windhoek Declaration and the Namibia Plan of Action and by those 15 Security Council members who unanimously voted to adopt resolution 1325 twenty years ago. The women in the many conflict-affected areas across the globe whose hopes and aspirations were raised by those milestone developments should not be let down any longer; they deserve so much better. By proceeding within the above parameters, and with enough commitment, focused engagement and action, and persistence by all of us - from grassroots activists to the highest echelons of power, from youth to wise elders across the global north and the global south, from marginalized communities to the privileged elites - we can collectively ensure that the following impassioned appeal made by Jamaica's Permanent Representative in her statement at the Security Council open debate on 24 October 2000 will finally be heeded:

The time has come for us to move from rhetoric to action. The women of the world expect no less from the Security Council.69

But, in assessing prospects for such transformative and accelerated change, there is a crucial question to be asked by each of us. Will this rallying cry be embraced during the upcoming $20^{\text {th }}$ anniversary commemorations of resolution 1325, and will sufficiently robust and decisive action be taken, with accompanying accountability, to precipitate another revolutionary outcome that will bring those much-overdue results?

69 See UN Doc. S/PV.4208, p. 12. 